\title{
Soil Conservation and the Reduction of Erosion and Sedimentation in the Coon Creek Basin, Wisconsin
}

GEOLOGICAL SURVEY PROFESSIONALAAPER 1234

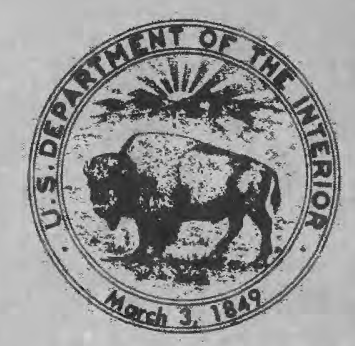




\section{Soil Conservation and the Reduction of Erosion and Sedimentation in the Coon Creek Basin, Wisconsin}

By STANLEY W. TRIMBLE and STEVEN W. LUND

GE OLOG I A L S UR VEY PROFES I O N A L P A P E R 1234

A study of changes in erosion and sedimentation after the introduction of soil-conservation measures

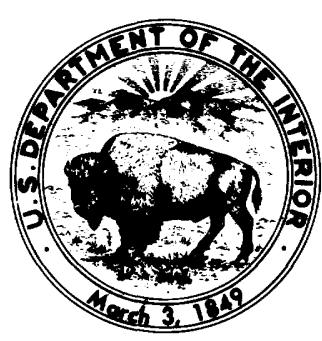




\title{
UNITED STATES DEPARTMENT OF THE INTERIOR
}

\author{
JAMES G. WATT, Secretary \\ GEOLOGICAL SURVEY
}

Dallas L. Peck, Director

Library of Congress Cataloging in Publication Data

Trimble, Stanley Wayne.

Soil conservation and the reduction of erosion and sedimentation in the Coon Creek Basin, Wisconsin.

(Geological Survey professional paper; 1234)

Bibliography: p.

1. Soil conservation-Wisconsin-Coon Creek watershed (Monroe County-Vernon County) 2. Soil erosion-WisconsinCoon Creek watershed (Monroe County-Vernon County) 3. Reservoir sedimentation-Wisconsin-Coon Creek watershed (Monroe County-Vernon County) 4. Coon Creek watershed (Monroe County-Vernon County, Wis.)

I. Lund, Steven W. II. United States. Geological Survey. III. Title. IV. Series. S624.W5T74 $631.4^{\prime} 5$ '0977554

$81-607057$ AACR2

For sale by the Distribution Branch, U.S. Geological Survey, 604 South Pickett Street, Alexandria, VA 22304 


\section{CONTENTS}

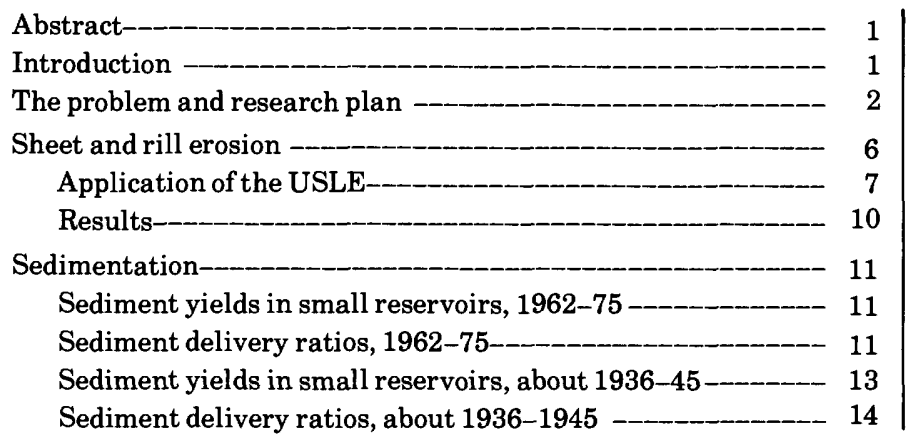

Sedimentation-Continued

Sediment deposition rates in the main valley, 1853-1976 --- 17

Relation of erosion and sedimentation to land use and management -_-_ 21

Climate as a variable _-_____________________________ 25

The Coon Creek area -_____ 25

The entire Driftless Area, 1867-1974 _-________ 27

Is Coon Creek representative? _-_ 29

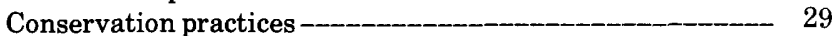

Conclusions-___ 30

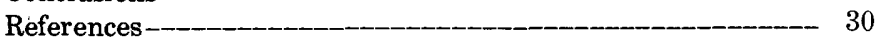

Appendices - 33

\section{ILLUSTRATIONS}

FIGURE 1. Location map showing the Coon Creek basin, subbasins, debris basins, valley cross sections, and other research locations mentioned in this study

2. Photographs of Coon Creek basin landscape, 1934 and 1967

3. Map showing changes of cropping patterns on the Stromstad farm, before and after conservation management-

4. Diagram showing decrease of drainage density between 1934 and 1967

5. Diagram showing land use in the Coon Creek area, 1850-1975

6. Schematic diagram showing sediment movement

7. Diagram showing changes of land use and management in 10 sample basins, Coon Creek, Wis., 1934 and 1967

8. Map showing subbasin 41

9. Map and diagram showing sediment accumulation in the Johnson Civilian Conservation Corps dam reservoir-_._-__-_-

10. Diagram showing sediment deposition rates at selected valley sites in Coon Creek basin, 1853-1977

11. Composite curve of sediment deposition for the main valley of Coon Creek basin, 1853-1975

12. Diagram showing sediment accumulation in small reservoirs of the Driftless Area, about 1936-45 and 1962-75

13. Photographs showing bank and channel erosion of perennial tributaries-

14. Graph showing erosion, sedimentation, and erosive land use, 1853-1975

15. Diagram showing the relation of erosion and sedimentation to erosive land use, 1853-1975

16. Photographs showing formation and healing of hillside gullies, 1905-78

17. Graph showing number of grazing animals, 1850-1975, and grazed forest, 1925-70, Vernon County, Wis.

18. Photographs showing deterioration of flood-plain pasture from accelerated sedimentation

19. Graphs showing precipitation trends in the Coon Creek area, 1927-73

20. Graphs showing precipitation trends in the Driftless Area, 1867-1974

21. Graphs showing precipitation trends at 15 selected stations in the Driftless Area, 1931-73-

22. Spread of contour-strip farming from the Coon Creek Conservation Demonstration Area, Wis., 1939-67

\section{TABLES}


TABLE 3. Assumptions made concerning land management and " $\mathrm{C}$ " factors

4. Average annual upland sheet and rill erosion rates for the study area, 1934 and 1975 , as calculated by the universal soil loss equation

5. Sediment-survey data, Coon Creek basin, 1962-75; sediment accumulated in 10 flood-retarding reservoirs constructed under Public Law 566

6. Accumulation of sediment in five small reservoirs, 1936-45

7. Management weighting factors to estimate erosive land use, 1853-1974

\section{APPENDICES}

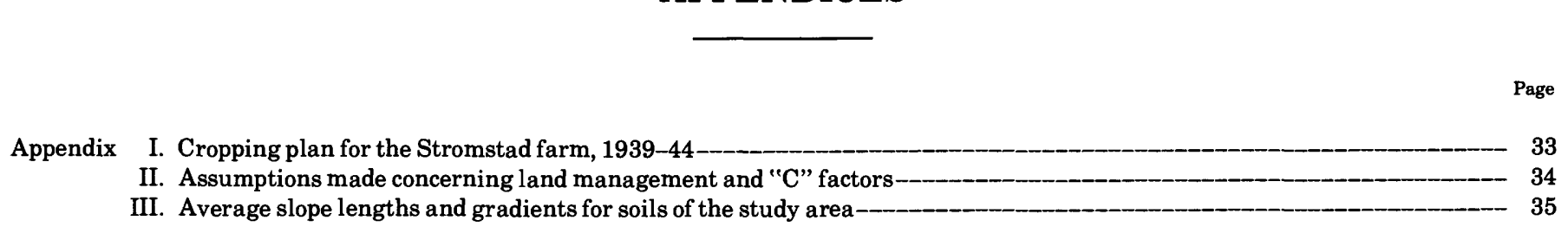

\section{Metric Conversion Table}

Metric units of length, area, volume, flow rate, and mass used in this report can be converted into inch-pound units as follows:

centimeter $(\mathrm{cm})$

inch (in)

kilometer $(\mathrm{km})$ -

kilometer ${ }^{2}\left(\mathrm{~km}^{2}\right)$ -

heter metare $^{3}\left(\mathrm{~m}^{3}\right)-$

meter ${ }^{3} / \mathrm{second}^{3}\left(\mathrm{~m}^{3} / \mathrm{s}\right)$-_____

megagram $(\mathrm{Mg})$

ton-

megagram $/$ kilometer $^{2}\left(\mathrm{Mg} / \mathrm{km}^{2}\right)$

ton $/ \mathrm{mile}^{2}\left(\right.$ tons $\left./ \mathrm{mi}^{2}\right)$ 


\title{
SOIL CONSERVATION AND THE REDUCTION OF EROSION AND SEDIMENTATION IN THE COON CREEK BASIN, WISCONSIN
}

\author{
By STANley W. TRImble ${ }^{1}$ and Steven W. LunD ${ }^{2}$
}

\begin{abstract}
The Coon Creek Basin in Wisconsin, like most of the Driftless Area, has been strikingly transformed by soil conservation measures since the 1930's. Greatly improved management measures, which include contour plowing, contour stripcropping, long rotations, crop residue management, cover crops, and controlled grazing, have been used. As a result, erosion and sedimentation have been greatly reduced.

Sheet and rill erosion in 1934 and 1975 were compared by use of the universal soil loss equation. Analysis of 10 subbasins comprising 9 percent of the study area indicated that the annual erosion rate in 1975 on upland fields ( $\bar{x}=720$ megagrams per square kilometer) was only about one-fourth that of the 1930 's $(\bar{x}=3,000$ megagrams per square kilometer).

Sedimentation rates were studied by two methods: (a) accumulation rates in small reservoirs and (b) deposition rates in the main valley. The sediment contents of 10 small reservoirs were surveyed for the period 1962-75, and 5 for various periods between 1936 and 1945. The average measured annual accumulation declined from about 4,800 megagrams per square kilometer (1936-45) to 63 megagrams per square kilometer (1962-75), but uncertainties concerning measurements for the early period make comparison difficult; the disparity may well be greater.

For deposition rates in tributary valleys, the total amount of sediment stored in these valleys was estimated by detailed measurements, and this amount was differentially budgeted over time on the basis of deposition rates in the main valley. This analysis indicated that net annual deposition rates had declined from about 3,700 megagrams per square kilometer in the 1930's to about 35 to 70 megagrams per square kilometer in recent years. Determination of a more exact rate for the present must await a sediment resurvey. By both the reservoir and valley sedimentation measures, present sedimentation rates are estimated to be only about 1 to 2 percent of the earlier rates.

These reductions in erosion and sedimentation have been caused principally by improvements in land management and, to a lesser degree, by changes of land use. For example, the area planted in crops did not change greatly, but the conservation management practices on that cropland were greatly improved. Erosion and sedimentation were functions of the erosive potential of land use (erosive land use), but both erosion and sedimentation demonstrated a time lag in their relationship to erosive land use. This lag increases with distance downstream and is caused mainly by (1) delayed changes of soil infiltration capacities, (2) delay in formation and growth of adequate upland and tributary channels to conduct increasing storm
\end{abstract}

\footnotetext{
${ }^{1}$ Department of Geography, University of California at Los Angeles, and U.S. Geological Survey.

${ }^{2}$ U.S. Army Corps of Engineers, Wilmington, N.C.
}

runoff peak and additional sediment, and (3) the time required for sediment to be transported downstream. Climatic changes may have imposed minor perturbations on the observed trends in erosion and sedimentation, but they do not seem to have been an important causal factor.

\section{INTRODUCTION}

How efficient has the soil conservation program been in the United States? Over 40 years of effort and many millions of dollars have been expended. Many valuable experimental data have been obtained, but there has been little information about effects of the conservation effort on the American landscape. This lack of applied information was lamented by Held and Clawson (1965, p. 232):

$* * *$ As we review the bits and pieces of evidence on the progress of soil conservation which we have put together***it is difficult to avoid a feeling of frustration. There are simply no clear-cut, welldesigned data, especially on a historical scale, which are adequate to answer the critical questions about soil conservation achievement over the past 30 years or so.***

Accelerated soil erosion has been widespread in the humid regions of the United States since European settlement (Butzer, 1975), and its anthropogenic causes are more readily documented than are those in arid regions (with respect to which there is still considerable controversy). For example, Trimble (1974) documented the rise and fall of accelerated erosion on the southern Piedmont, where erosion became serious after European settlement, about 1700 , and was not brought under control generally until after 1940, but the data used in that study were largely qualitative. Moreover, the decline of erosion in that area was more the result of changes in land use, with reversion of cropland to forests and pasture, than of changes in land-management practices, whereas, for much of the United States, land that was used for crops in the 1930's has continued to be so used.

A better opportunity to document the effectiveness of soil conservation efforts is provided by data 
available for the Coon Creek basin (fig. 1) in the Driftless Area of Wisconsin, a submaturely dissected plateau with local relief of about 135 meters, steep valley sides, and narrow valleys. The Driftless Area derives its name from the absence of deposits from continental glaciers that surrounded the area during the Pleistocene. The rock in the study area is sedimentary, with coherent to very friable sandstones and fractured shales overlain by a relatively resistant dolomite that underlies the rolling upland surface of the plateau. These uplands and milder slopes are capped with Pleistocene loess, and the alluviated valleys are partly filled with a series of alluvial terraces, probably of Pleistocene age (McKelvey, 1939, p. 13). At the time of European settlement, hillside swales and draws were partly filled with debris from former erosional episodes. This debris ranged in size from sand to dolomitic boulders. Although apparently stable at the time of European settlement, many were later cut by gullies and provided much sediment.

This severely eroded Coon Creek basin was designated the Nation's first conservation demonstration area. When the conservation efforts were started in 1933, the area showed the effects of 80 years of poor land management: soils had been both depleted and eroded. Sediment from sheet, rill, and channel erosion was more than the streams could transport, and the main valleys were rapidly filling; as much as 2 meters of vertical accretion had occurred in 10 years (McKelvey, 1939). Part of the basin in early 1934 is shown in figure $2 A$; figure $3 A$ shows cropping patterns on the farm outlined at the right side of figure $2 A$. The area was characterized in 1934 by rectangular fields on rolling to steep slopes (figs. 2,3), poor crop rotations, removal of crop residues, insufficient manuring, nutrient depletion, lack of cover crops, and very active erosion. Pastures and woodland were overgrazed, compacted, and eroding in many places. The high drainage density, composed of eroded rills and gullies, provides evidence of extensive erosion caused by high rates of overland flow (fig. 4A). Many gullies, supplied with overland flow mainly from cropped areas of the rolling uplands, extended downslope through steep wooded areas. These woodland gullies were especially serious because they dissected old hillside sediment deposits. This coarser sediment was easily transportable down the steep slopes onto flood plains and into stream channels. Additionally, the channels of small stream tributaries were usually trenched from the high runoff peaks, thereby furnishing additional sediment downstream.

By contrast, present-day land management features contour plowing and contour stripcropping (figs. $2 B$ and $3 B$ ). Management practices include long rota- tions, incorporation of crop residues into the soil, manuring, and cover crops (Appendix I). Figures 2 and 3 show that land use has changed little, except on very steep areas, and the major change has been improved land management. The overall trend in land use since European settlement (about 1850) may be summarized as follows: the area of cultivated land generally expanded until about 1900 and has declined slightly but continually since that time (fig. 5). Although obvious effects of erosion (rills and gullies) on present cropland still occasionally exist, they are uncommon. Pastures are well managed with good cover, whereas woodlands are generally less grazed or ungrazed and therefore more dense. The rills and gullies have mostly disappeared (fig. 4). It is reasonable to assume that improved land-management practices have increased infiltration. Thus, an increasing proportion of the runoff from upland slopes has been changed from overland flow, which characterizes bare, disturbed areas, to subsurface flow, which had probably characterized the primeval landscape of prairie upland and forested slopes.

Acknowledgments. - The authors of this report wish to thank several government groups, institutions, and individuals for their help in the successful completion of this project. The U.S. Geological Survey; the U.S. Soil Conservation Service; the Wisconsin Department of Natural Resources; the Wisconsin Department of Transportation, Division of Highway; and the University of California provided financial and logistical support. S. C. Happ, who designed a long-range sediment study for the valley in 1938, provided valuable field assistance and advice. Many students from the University of California at Los Angeles and the University of Wisconsin at Milwaukee assisted with both field work and office work. Area residents, who allowed access to their property for data collection, were extremely cooperative and helpful. Technical and administrative individuals too numerous to mention are also gratefully acknowledged.

\section{THE PROBLEM AND RESEARCH PLAN}

Demonstration of the effectiveness of soil conservation measures required ascertaining the quantitative changes of erosion and sedimentation between the mid-1930's and the present time and determining the relation between any such changes and improved conservation measures. On the basis of the qualitative evidence available, we believed that both erosion and sedimentation have been reduced significantly. On both procedural and conceptual grounds, it seemed best to separate the examination of erosion from that of 
THE PROBLEM AND RESEARCH PLAN

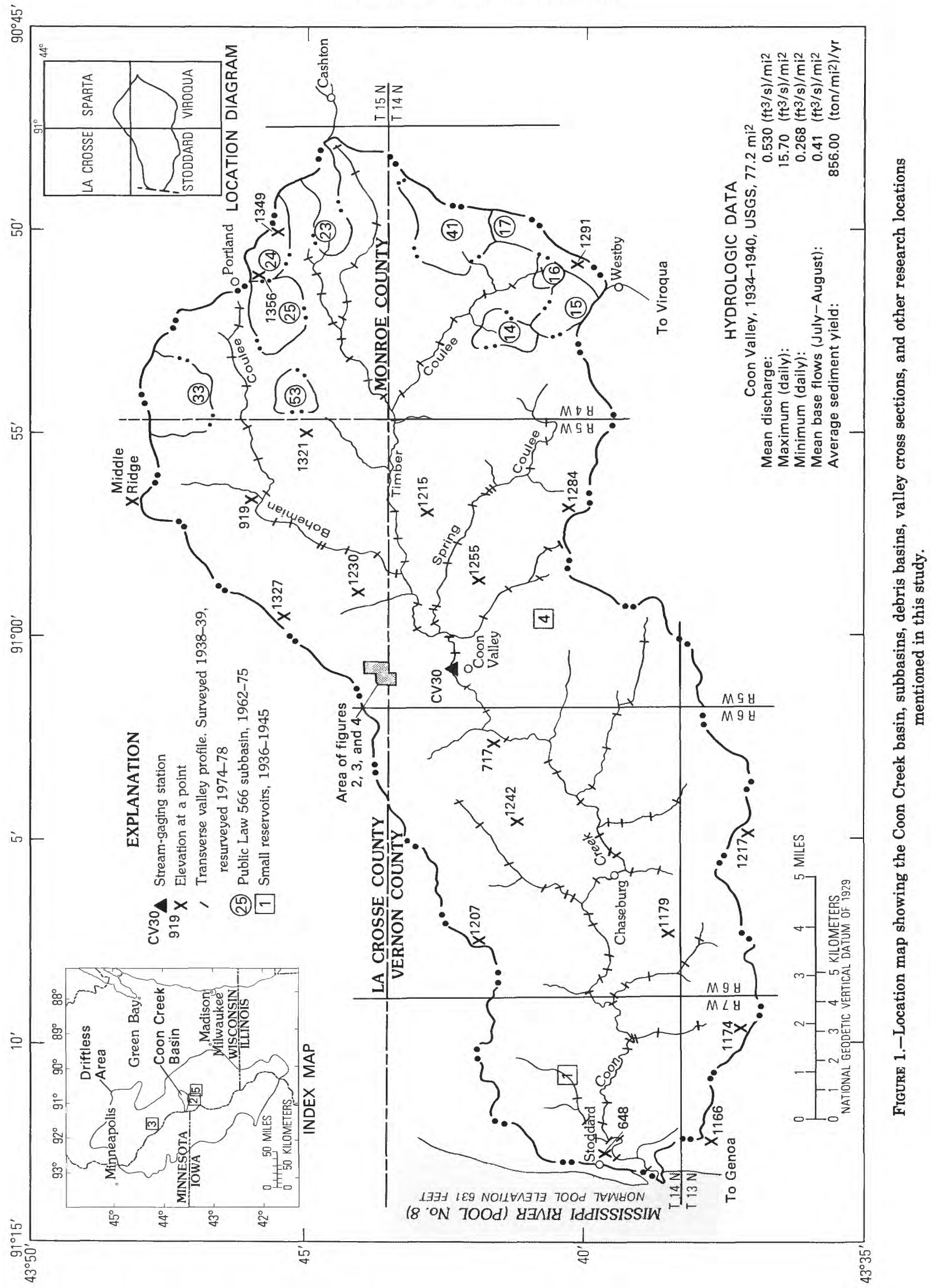



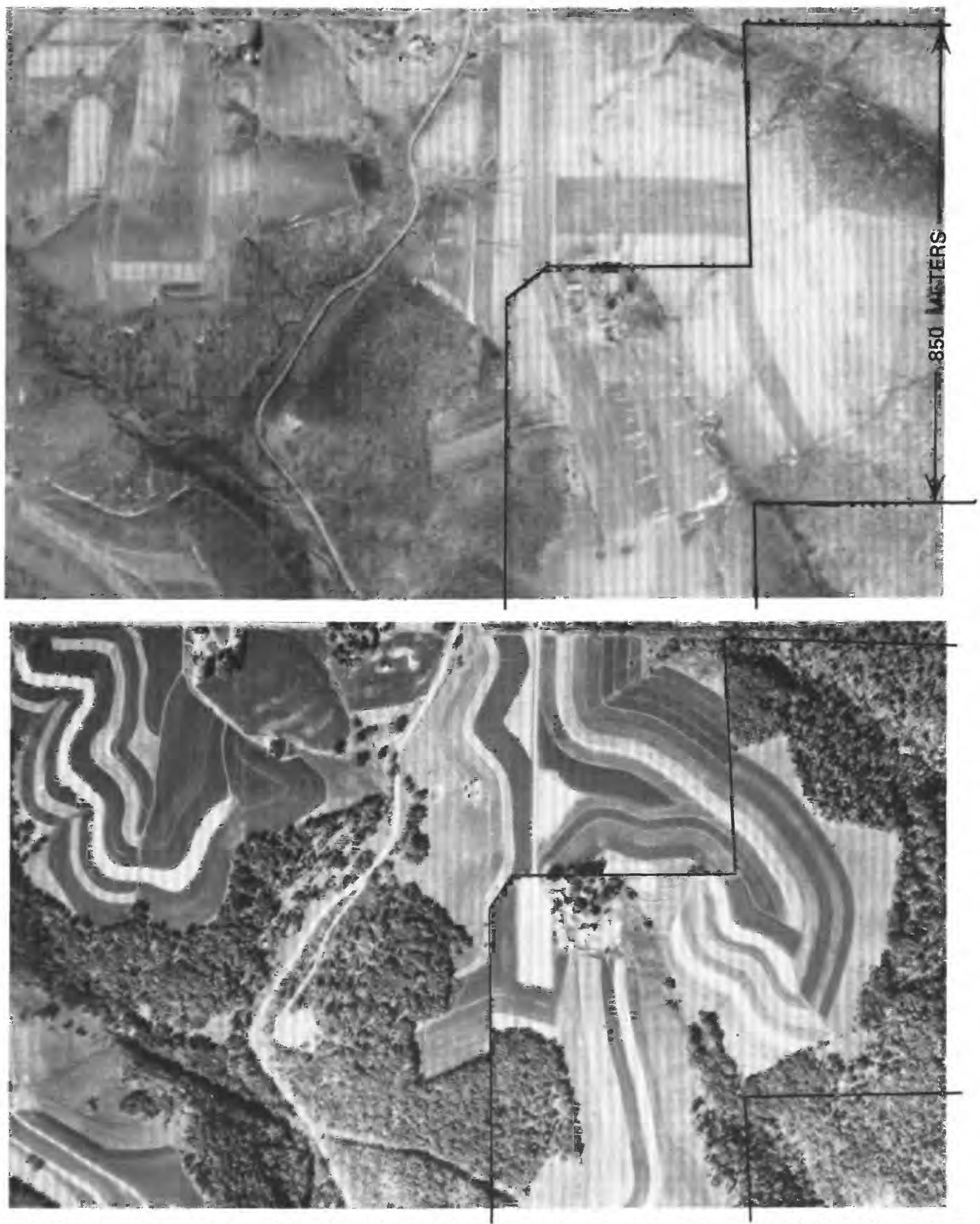

Figure 2.-Coon Creek basin landscape, 1934 and 1967. Location shown in figure 1; details shown in figure 3. A, Early 1934. Note rectangular fields and gully systems extending into the upland cultivated fields. $B, 1967$. Note contoured and stripcropped fields. Photographs by U.S. Department of Agriculture. 

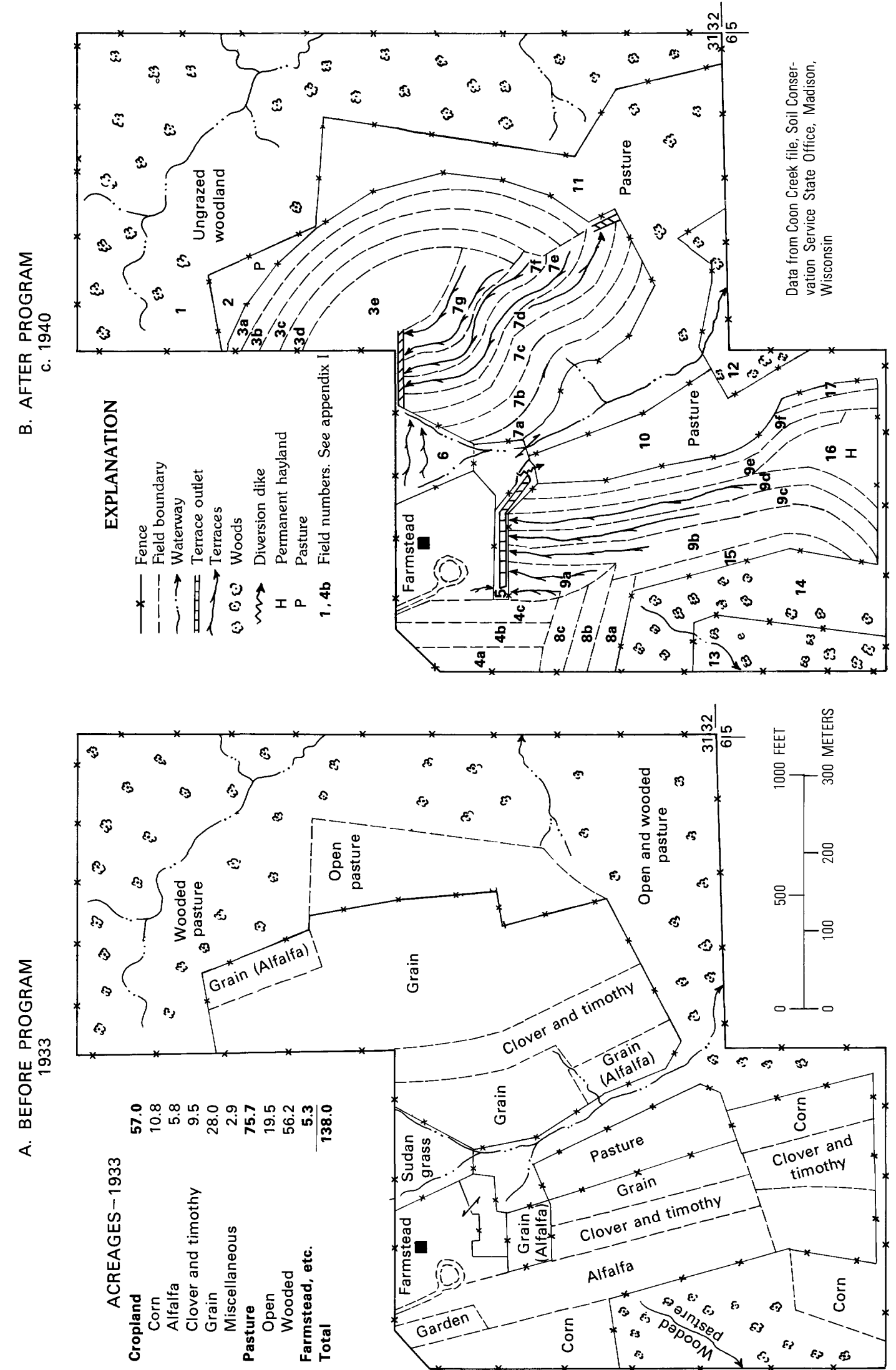


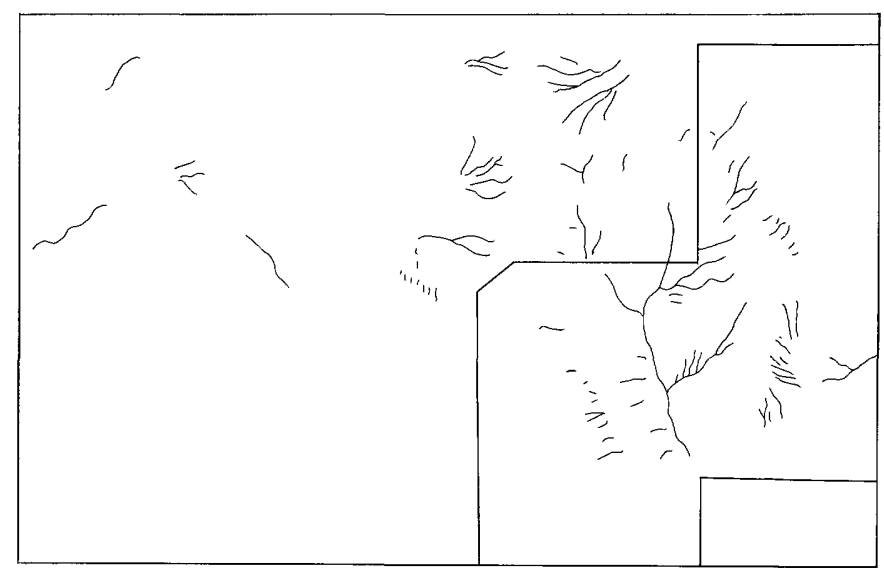

A. 1934

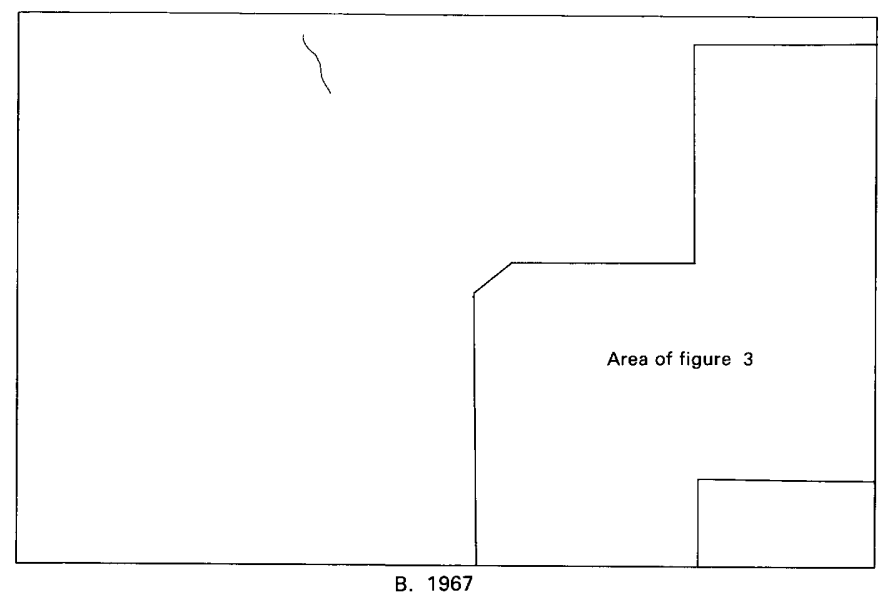

FIgURE 4.-Decrease of drainage density between 1934 and 1967. Shown are channels detectable on open land from airphotos (fig. 2). Outlined area is that of figure 3 . Location is shown in figure 1 .

sedimentation, with the sedimentation analysis designed as general field corroboration of the erosion data.

Stream-sediment yields have long been used as the indicator of upland erosional processes. A steady state, or balance between material transported by the stream and that produced on the slopes, has been assumed to exist. Now we know that this concept of steady state is an oversimplification because much of the sediment flux is interrupted by periods of sediment storage between the upland slopes and the downstream point where sediment yield is measured. Unless these storage fluxes are accounted for, there can be little meaningful analysis of erosional phenomena and their causal factors (Trimble, 1975, 1977, in press).

A schematic chart (fig. 6) of sediment flux within a basin shows that material eroded from the upland slopes has three immediate routes: it can be deposited within the basin either as colluvium or as alluvium, or it can be transported directly out of the basin to provide immediate sediment yield. Material deposited as colluvium can later be dissected and then redeposited as colluvium or alluvium, or it can be moved out of the basin. Alluvium can be eroded from the channel or flood plain and then transported from the basin, or it too can be redeposited farther downstream as alluvium.

Some factors controlling sediment delivery are listed in table 1. Together, these factors act as a "screen" permitting more or less of the eroded material to leave as sediment yield. Table 1 covers a relatively short period (up to a few decades).

TABLE 1.-Examples of morphologic and process factors that affect rates of sediment delivery

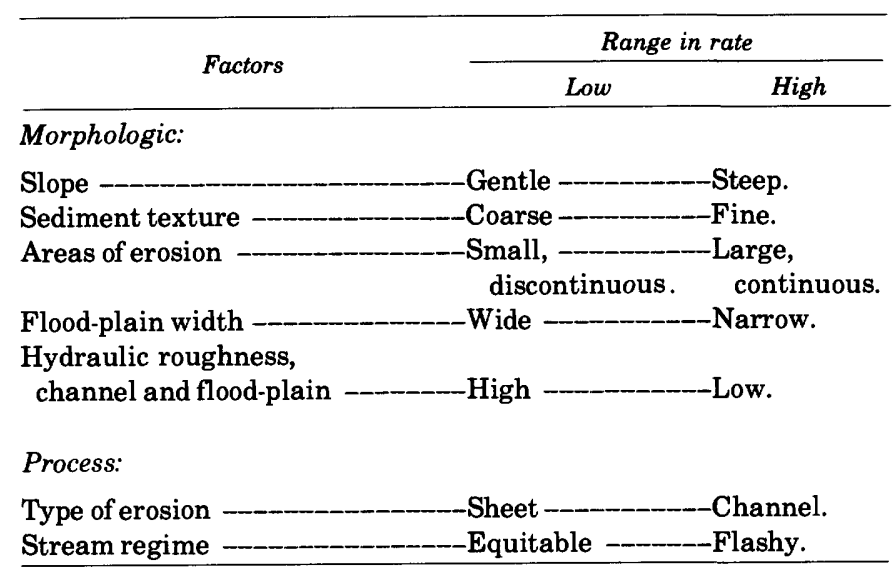

Steady state or equilibrium is a useful concept in the analysis of the sediment budgets of stream basins. Under this concept, eroded material equals sediment yield, or, expressed another way, the net sediment storage flux is zero. However, such an ideal condition rarely exists in nature, if ever, and it is necessary to speak of disequilibria. If the gain of storage during a given period is greater than the loss of storage, then a positive disequilibrium exists, characterized by net storage gain and consequent aggradation of slopes and (or) channels and (or) flood plains. This condition has characterized many disturbed basins in the past (Trimble, 1975a, 1977, in press). If storage loss is greater than storage gain, then a negative disequilibrium exists whereby erosion of sediment deposits, especially channels and flood plains, is dominant and a consequent net sediment loss occurs.

\section{SHEET AND RILL EROSION}

Upland sheet and rill erosion in the Coon Creek basin was evaluated by use of the universal soil loss 


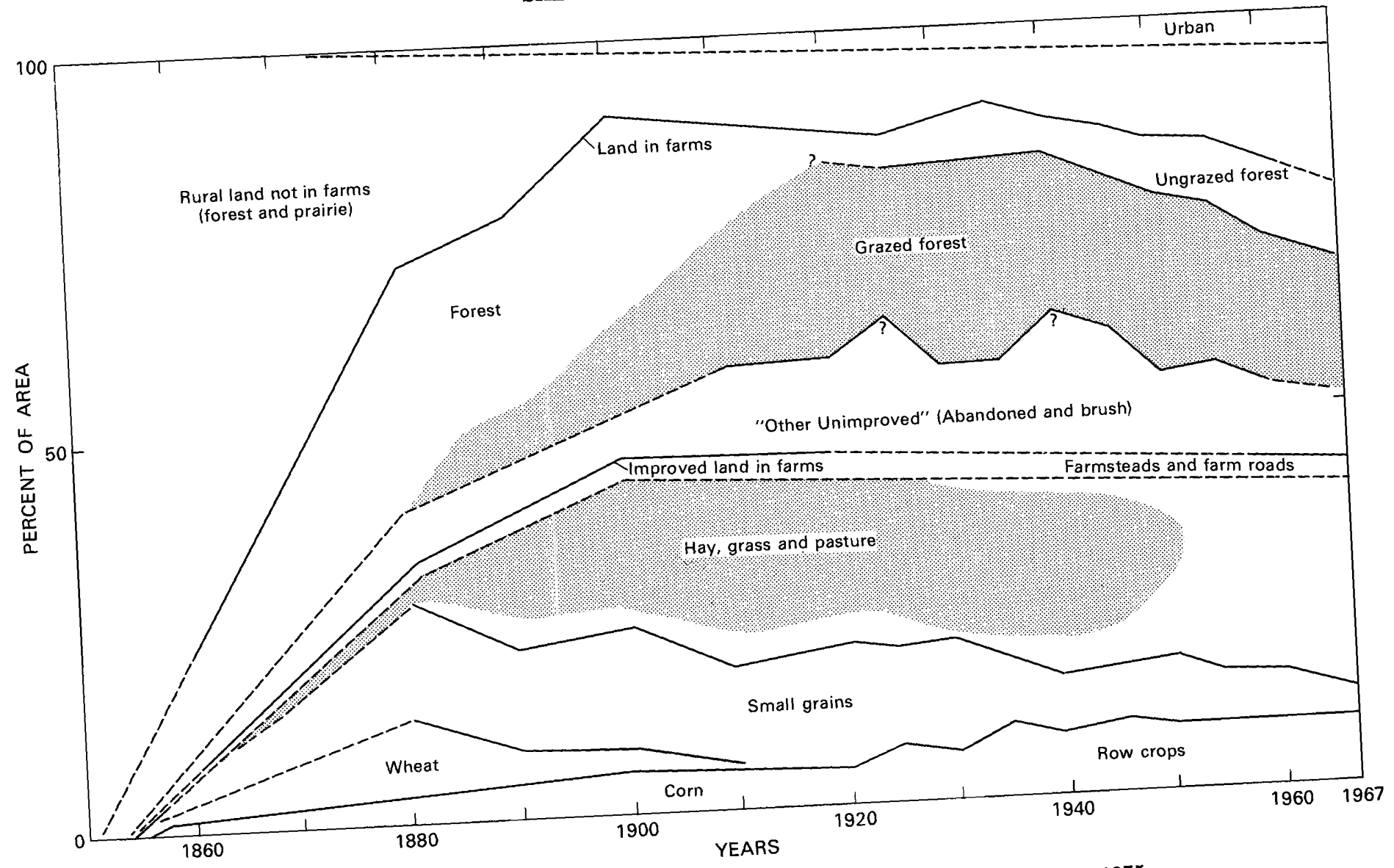

Figure 5.-Diagram showing percentage changes in land use, Coon Creek area, 1850-1975.

SOURCE

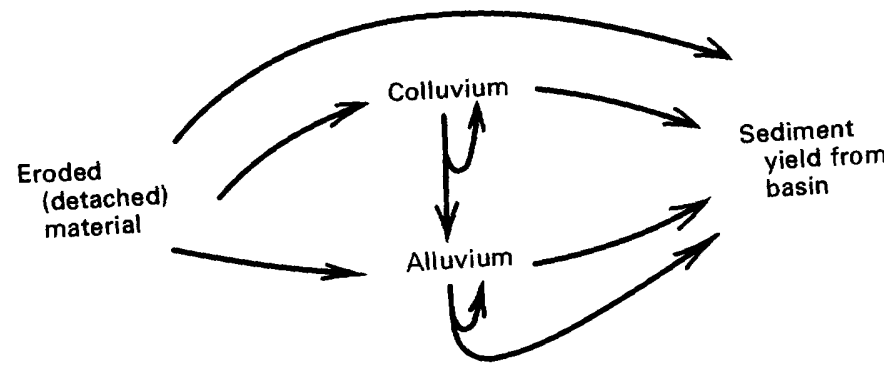

FIGURE 6.-Schematic diagram showing sediment movement.

equation (USLE). Ten subbasins ranging in size from 85.6 ha (214 acres) to $607 \mathrm{ha}(1517$ acres) were analyzed for the years 1934 and 1967 (fig. 1). The selection was not random: the basins are tributary to flood-retarding reservoirs built in 1961-63 under Public Law 566. Thus, sediment yields measured in these reservoirs can be compared to calculated erosion. An additional criterion for selection was the availability of airphoto coverage for both 1934 and 1974. We believe these sample basins to be representative of the agricultural landscape for the 1930's, but, as a result of special land treatment related to Public Law 566, these basins possibly have somewhat better than average land management at present. Also, the sample basins are located in the headwaters where local relief is general ly less than the average relief for the entire Coon Creek basin.

\section{APPLICATION OF THE USLE}

Upland soil losses from sheet and rill erosion were computed by using the USLE, which states that $A=$ $R K L S C P$, or the amount of soil loss in tons per acre per year $(A)$ equals the product of the rainfall factor $(R)$, the soil erodibility factor $(K)$, the slope-length factor $(L)$, the slope-gradient factor $(S)$, the cropping managefactor $(C$, a combination of land use and land management), and the erosion control practice factor $(P)$ (Wischmeier and Smith, 1965).

The equation was applied to the study area according to methods of the U.S. Department of Agriculture, 
Soil Conservation Service (1975). More specialized information concerning the equation factors came from the Soil Conservation Service (1973a) and from addenda from the Soil Conservation Service office in Madison, Wis.

The 10 subbasins (fig. 1) were outlined on soil maps of the U.S. Department of Agriculture, and soilmapping units were then delineated. Data on land use were taken from U.S. Department of Agriculture airphotos for 1934 and 1974. This procedure divided the landscape into parcels on the basis of soil, slope, previous erosion, and land use. Land-use acreages for both periods are given in table 2 and figure 7. Data on present land management were obtained from individual farm-conservation plans and from Soil Conservation Service personnel. Predominant land-management methods of the early 1930's were provided by landinventory surveys (Wisconsin Department of Agriculture, undated) and from Soil Conservation Service personnel and others familiar with conditions of that time. The percentage of area controlled by Soil Conservation Service cooperators, persons who usually conform to prescribed soil management practices, is shown in figure $7 A$. At present, noncooperators usually emulate their neighbors to various degrees so that much land not under a formal agreement is still given moderate to good management. In contrast, in 1934 , practically no one practiced good soil-conservation practices in the Coon Creek basin. A few did try to contour and to use stripcropping, but their methods were often crude and ineffective.

Figure $7 B$ shows the changes in land management on selected uses. As mentioned, some contouring and stripcropping were initiated in the Coon Creek basin by 1934 , but the 1934 airphotos show none in the sampled subbasins. The fact that 38 percent of present cropland is neither contoured nor stripcropped (fig. $7 B$ ) is compatible with acceptable management practices because most of the nontreated land is on the more gentle slopes of the rolling upland.

Crop rotations are also greatly improved (fig. $7 B$ ), with longer periods in grass cover which not only offers more soil protection but also increases the soil's resistance to erosion during periods when it is under

TABLE 2.-Land use in 10 subbasins, 1934 and 1975. Locations of subbasins shown in figure 1; data compiled from Lund, 1976, table 8

\begin{tabular}{|c|c|c|c|c|c|c|c|}
\hline & \multicolumn{3}{|c|}{1934} & \multicolumn{3}{|c|}{1975} & \multirow{2}{*}{$\begin{array}{l}\text { Change, } \\
1934-75 \\
\\
\text { Percent }\end{array}$} \\
\hline & Hectares & Acres & Percent & Hectares & Acres & Percent & \\
\hline $\begin{array}{l}\text { Cropland } \\
\text { Pasture- } \\
\text { Woodland } \\
\text { Farmyards } \\
\text { Roads and buildings } \\
\quad \text { Total }\end{array}$ & \begin{tabular}{|r}
$-2,055$ \\
$-\quad 553$ \\
$-\quad 474$ \\
$-\quad 29$ \\
$-\quad 3,181$
\end{tabular} & $\begin{array}{r}5,138 \\
1,383 \\
1,184 \\
174 \\
72 \\
7,951\end{array}$ & $\begin{array}{r}64.6 \\
17.4 \\
14.9 \\
2.2 \\
1.9 \\
100\end{array}$ & $\begin{array}{r}1,937 \\
622 \\
522 \\
68 \\
32 \\
3,181\end{array}$ & $\begin{array}{r}4,842 \\
1,556 \\
1,304 \\
170 \\
79 \\
7,951\end{array}$ & $\begin{array}{r}60.9 \\
19.6 \\
16.4 \\
2.1 \\
1.0 \\
100\end{array}$ & $\begin{array}{l}-5.8 \\
+12.5 \\
+10.1 \\
-2.3 \\
+9.7\end{array}$ \\
\hline
\end{tabular}

row crops. For example, 80 percent of all cropland is now in a rotation of 1 year of row crops, 1 year of oats, and 3 years of hay $(\mathrm{RO} 3 \mathrm{H}$, fig. $7 B$ ). Besides immediately reducing erosion, the long periods of grass cover between row crops are important in replacing organic material, improving soil structure, increasing infiltration, and increasing fertility, factors which eventually further reduce erosion. All these effects are greatly reinforced by the prevalent good crop-residue management. At present (1975), only 1 percent of cropland has no rotation. We do not have a comparable figure for 1934, but we assume that lack of crop rotation was more prevalent than it is at present. Even though crop rotations were common in 1934 , the grass cover was usually not maintained sufficiently long to allow the soil to recover from the depleting effects of row crops and small grains.

Most woodland in the Coon Creek basin was heavily grazed in 1934 (fig. 7). Most of the forest understory was removed, and the soil was heavily compacted and disturbed. Grazing was commonly severe enough to kill trees (Soil Conservation Service, undated, p. 18). Grazed woodland areas were eroding seriously, and the resultant runoff damaged downslope fields. At present only 22 percent of woodland is grazed, and this grazing is usually light and not as destructive as that of the 1930's.

Despite our efforts to determine precisely the landmanagement portion of the cropping management factor $C$, the exact condition of every land parcel in 1934 could not be established. Therefore, application of the USLE required some uniform assumptions (table 3), which do not apply to every site, although they are believed to be correct as the general rule.

The rainfall factor, $R$, is a numerical measure of the annual erosivity. It is obtained by summing the products of total kinetic energy and maximum 30-minute intensity $(E I)$ for each storm during the year (Wischmeier and Smith, 1965). The $R$ value used in the USLE for both 1934 and 1975 is the average annual $E I$ value for long-term weather records. The Soil Conservation Service has computed average $R$ values for counties of Wisconsin, that of Vernon County being 150.

The soil erodibility factor, $K$, reflects the fact that some soils are eroded more readily than others, even where slope, rainfall, cover, and management are the same. $K$ factors have been determined through field experimentation by the U.S. Department of Agriculture for all of Wisconsin. The most erodible soils in the study area are about one-third more erodible than the least erodible soils.

The slope length factor, $L$, is the distance from the point of origin of overland flow to either the point 

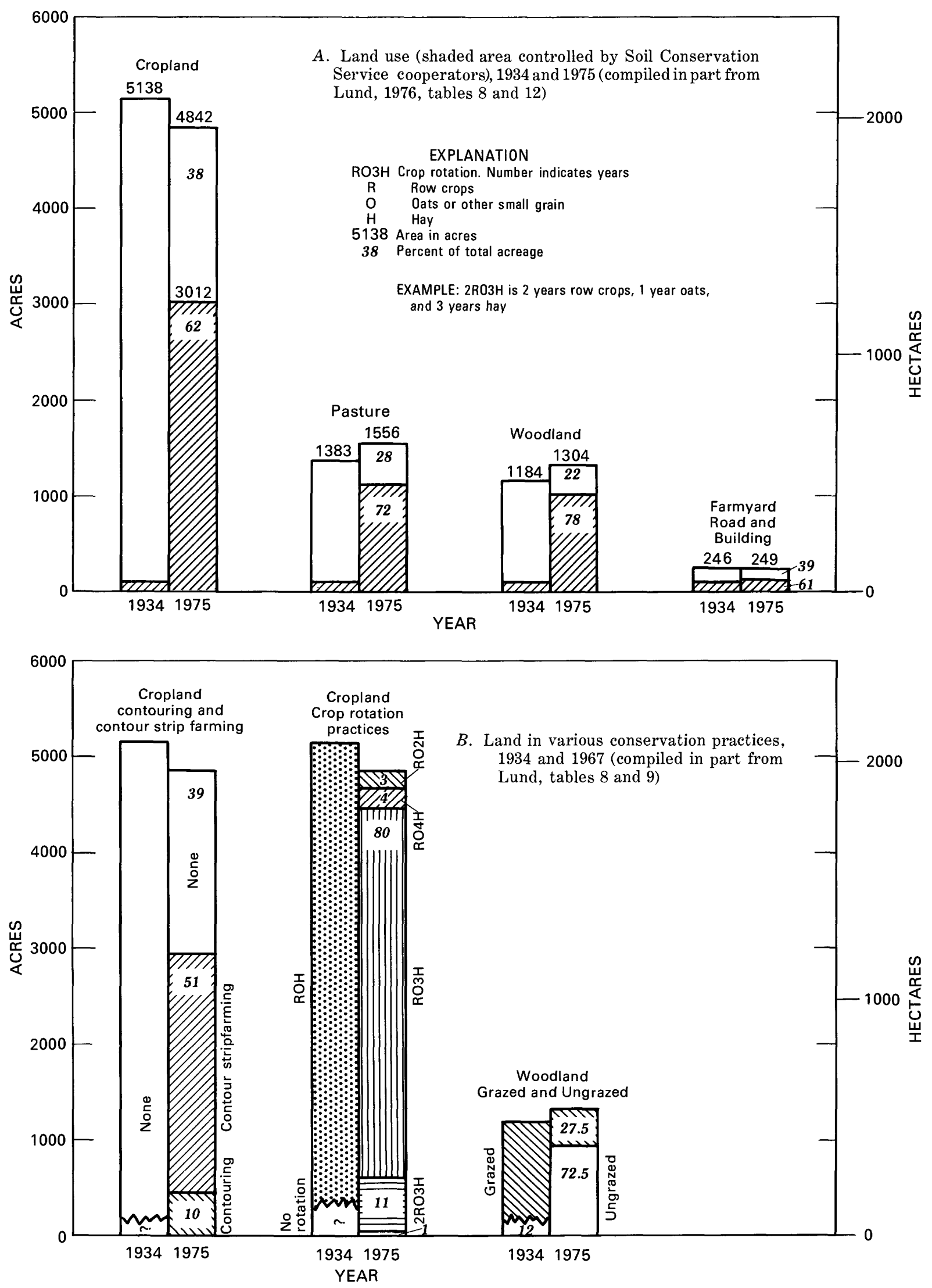

Figure 7.-Diagram showing changes of land use and management in 10 sample basins, Coon Creek, Wis., 1934 and 1974. 
TABLE 3.-Sample soil-loss computations for part of the individual soil mapping units in subbasin 15 using the universal soil loss equation, $A=R K L S C P$

[ $A$ is computed to give an annual rate in tons per acre. The component variables $R, K, L, S, C$, and $P$ are dimensionless. $A$, amount of soil loss; $R$, rainfall factor; $K$, soil erodibility factor; $L$, slope length factor; $S$, slope gradient factor; $C$, cropping management factor; $P$, erosion control practice factor]

\begin{tabular}{|c|c|c|c|c|c|c|c|c|c|c|c|}
\hline Soil Unit & Land Use & Area (acres) & $R$ & $K$ & $L$ & $S$ & $L S$ & $C$ & $P$ & \multicolumn{2}{|c|}{$\begin{array}{c}A \\
\text { Annual Rates }\end{array}$} \\
\hline \multicolumn{12}{|c|}{1934} \\
\hline \multirow{2}{*}{\multicolumn{3}{|c|}{ ArA -road -- $\quad 0.1$}} & - & - & - & - & - & - & - & - & - \\
\hline & & & 150 & 0.28 & 400 & 1 & 0.27 & 0.04 & 1.0 & 0.45 & 102 \\
\hline \multicolumn{3}{|c|}{$\mathrm{CaB}-\ldots$} & 150 & .32 & 200 & 4 & .58 & .10 & 1.0 & 2.28 & 632 \\
\hline & pasture- & -8.4 & 150 & .32 & 200 & 4 & .58 & .04 & 1.0 & 1.1 & 252 \\
\hline & 150 & .37 & 350 & 16 & 5.37 & .04 & 1.0 & 11.9 & 2,710 \\
\hline \multicolumn{3}{|c|}{$\begin{array}{r}\text { DsD2 -rosture-1 } \\
\text { crop- }-11.2\end{array}$} & 150 & .37 & 350 & 16 & 5.37 & .10 & 1.0 & 29.8 & 6,870 \\
\hline \multicolumn{3}{|c|}{ DsE -__-_pasture-_-_-_-_-_ 5.2} & 150 & .37 & 250 & 25 & 8.50 & .04 & 1.0 & 18.9 & 4,290 \\
\hline \multicolumn{3}{|c|}{ DvE - } & 150 & .37 & 200 & 25 & 8.50 & .04 & 1.0 & 18.9 & 4,290 \\
\hline & wood -- - & ---4.0 & 150 & .37 & 200 & 25 & 8.50 & .03 & 1.0 & 14.2 & 3,220 \\
\hline \multicolumn{3}{|c|}{ FvD2 ------crop--_- } & 150 & .37 & 300 & 16 & 4.97 & .10 & 1.0 & 27.6 & 6,270 \\
\hline \multicolumn{12}{|c|}{1975} \\
\hline \multicolumn{3}{|c|}{ ArA - - } & - & - & - & - & - & - & - & - & - \\
\hline & pasture- & 7.5 & 150 & 0.28 & 400 & 1 & 0.27 & 0.011 & 1.0 & 0.1 & 627 \\
\hline \multicolumn{3}{|c|}{ 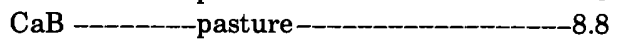 } & 150 & .32 & 200 & 4 & .58 & .011 & 1.0 & .3 & 70 \\
\hline \multirow[t]{3}{*}{ DsD2 -- } & -wood - & -2.0 & 150 & .37 & 350 & 16 & 5.37 & .03 & 1.0 & 8.9 & 2,030 \\
\hline & pasture- & -15.8 & 150 & .37 & 350 & 16 & 5.37 & .011 & 1.0 & 3.3 & 746 \\
\hline & crop---- & --2.4 & 150 & .37 & 350 & 16 & 5.37 & .055 & .9 & 14.8 & 3,350 \\
\hline \multirow{3}{*}{\multicolumn{3}{|c|}{ 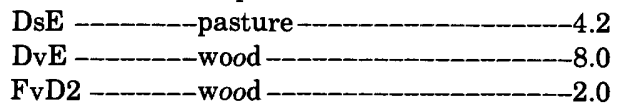 }} & 150 & .37 & 250 & 25 & 8.50 & .011 & 1.0 & 5.2 & 1,180 \\
\hline & & & 150 & .37 & 200 & 25 & 8.50 & .001 & 1.0 & .5 & 167 \\
\hline & & & 150 & .37 & 300 & 16 & 4.97 & .001 & 1.0 & .3 & 61 \\
\hline
\end{tabular}

where deposition begins as the slope decreases or the point where runoff enters a well-defined channel that may be part of a natural drainage network or a constructed channel such as a waterway or diversion. Average slope lengths for the soil mapping units of the study area were used in the computations (Appendix 3). These average slope lengths, supplied by the State Office of the Soil Conservation Service in Madison, are based on actual field measurements in the region of the study area. Average slope lengths were used because the areal extent of the study area prohibited making direct measurements for each field and because the large local relief of the area made it difficult to obtain accurate measurements from aerial photographs. Also, the point of origin of overland flow or the point of deposition of colluvium cannot always be determined from aerial photos. Average slope lengths are used by Soil Conservation Service personnel in watershed and soil-conservation planning, and we desired to follow standard Soil Conservation Service procedures as closely as possible in soil loss computations so that our study could be duplicated.

The slope gradient factor, $S$, expresses the effect of the inclination of the land surface. The average slope for each class was used for calculations. For field application, slope length and slope gradient are combined into a single topographic factor, $L S$, to adjust the soil- loss estimate for effects of length, steepness, and shape of the slope. This conversion is done by use of a slopeeffect chart (Soil Conservation Service, 1973a).

Examples of soil-loss computations by soil mapping units are given in table 3 . These comprise about a quarter of the computations required for subbasin 15 alone.

\section{RESULTS}

Calculated annual erosion rates from the 10 subbasins in 1934 ranged from 1,900 to $3,900 \mathrm{Mg} / \mathrm{km}^{2}$ with an area-weighted average of $3,000 \mathrm{Mg} / \mathrm{km}^{2}$ (table 4). In 1975 , the values ranged from 420 to $1,100 \mathrm{Mg} / \mathrm{km}^{2}$, with an annual area-weighted average of $720 \mathrm{Mg} / \mathrm{km}^{2}$. Thus, the present annual rate of upland erosion is calculated to be less than one-fourth that of 1934 . We place more importance on the relative rates than on the absolute soil-loss values.

These data should be used only with at least two stipulations or warnings. First, we have calculated only upland sheet and rill erosion on fields; these figures are not equivalent to sediment yields downstream. Gully erosion, although not a significant sediment source at the present time, was significant in 1934 (figs. 2 and 4). Running water confined to channels normally cuts much faster than thin sheet and rill flow, which encounters far more frictional resistance. 
TABLE 4.-Average annual rates of upland sheet and rill erosion for the study area, 1934 and 1975, as calculated with the universal soil loss equation. Locations of subbasins shown in figure 1.

\begin{tabular}{|c|c|c|c|c|c|}
\hline \multirow[b]{2}{*}{ Subbasin } & \multicolumn{2}{|c|}{1934} & \multicolumn{2}{|c|}{1975} & \multirow{2}{*}{$\frac{1975 / 1934}{\text { (percent) }}$} \\
\hline & $\left(\mathrm{Mg} / \mathrm{km}^{2}\right)$ & (Tons/mi') & $\left(\mathrm{Mg} / \mathrm{km}^{2}\right)$ & (Tons/mi $\left.{ }^{2}\right)$ & \\
\hline 14 & 3,700 & 10,600 & 690 & 2,000 & 19 \\
\hline 15 & 3,000 & 8,600 & 650 & 1,900 & 22 \\
\hline 16 & 2,800 & 8,000 & 870 & 2,500 & 31 \\
\hline 17 & 2,600 & 7,400 & 580 & 1,700 & 22 \\
\hline 41 & 2,800 & 8,000 & 860 & 2,500 & 31 \\
\hline 23 & 1,900 & 5,400 & 420 & 1,200 & 22 \\
\hline 24 & 3,300 & 9,400 & 1,100 & 3,100 & 33 \\
\hline 25 & 3,900 & 11,100 & 610 & 1,700 & 16 \\
\hline 33 & 3,300 & 9,400 & 670 & 1,900 & 20 \\
\hline 53 & 3,500 & 10,000 & 730 & 2,100 & 21 \\
\hline
\end{tabular}

Area-weighted

\begin{tabular}{lllll} 
Average-- 3,000 & 8,600 & 720 & 2,100 & 24 \\
\hline
\end{tabular}

Second, the index of soil erodibility for the USLE, the $K$ factor, is based simply on soil series and takes no cognizance of specific soil conditions. That is, by 1934 most soils in the study area had been abused for about 80 years, and, given the lack of management practices, it appears reasonable to assume that these soils had undergone cumulative deterioration and were in poor hydrologic condition; that is, with little organic material, few roots and root channels, depleted nutrients, and a high degree of compaction. Erosion from these soils further aggravated the condition because most subsoils (B horizon) are more erodible. For example, the subsoils of two regionally dominant soils, the Fayette and Palsgrove series are about 16 percent more erodible than their topsoils (Soil Conservation Service, Madison, Wis., unpublished mimeographed data, February 1977). The management practices of the past 30 years, such as residue management and the maintenance of grass cover for longer periods, could only improve soil conditions. Because the 1934 rates were possibly higher than our calculations indicate, the 1934-75 disparity may be greater than our 4-to-1 figure. Thus, we consider our calculations as a minimum change in rate.

Experiments in the Driftless Area near Coon Creek gave results similar to our estimated erosion rates. They indicated that 2 years of grass cover in a rotation was essential for minimum conservation on steeper slopes and that 3 years was even more beneficial (Hays and others, 1949). Under otherwise identical conditions, when rotation with only 1 year of grass cover lost an annual average of $2,200 \mathrm{Mg} / \mathrm{km}^{2}$, rotation with 2 years of grass cover lost only $1,300 \mathrm{Mg} / \mathrm{km}^{2}$ per year, rotation with 3 years of grass cover lost $800 \mathrm{Mg} / \mathrm{km}^{2}$, and rotation with 4 years of grass cover lost only 700 $\mathrm{Mg} / \mathrm{km}^{2}$. Additionally, the change from contour plow- ing to contour stripcropping reduced soil losses by $\mathbf{5 0}$ percent.

\section{SEDIMENTATION}

We have attempted to measure sedimentation in two environments for both time periods. The environments are (1) total sediment yield in small tributary reservoirs or flood-retention structures with high sediment trap efficiencies and (2) deposition rates for modern alluvium in the main valley, storage of which accounts for much of the fluvial sediment generated since European settlement.

\section{SEDIMENT YIELDS IN SMALL RESERVOIRS, 1962-75}

Each of the 10 subbasins (fig. 1) was selected primarily because it was tributary to a flood-retention reservoir which acts as an efficient sediment trap. These reservoirs, built during 1960-63 (one built in 1963) had collected most of the sediment delivered from their tributaries' basins when the sediment surveys were made in 1975 . These surveys were done according to Soil Conservation Service standards using cross-sectional profiles or ranges and borings through the sediment accumulation (Soil Conservation Service, 1971). Figure 8 shows one subbasin and its reservoir with the sediment survey profiles. Characteristics of the reservoirs and the sediment measurements are given in table 5. Annual sediment yields ranged from 8 to $131 \mathrm{Mg} / \mathrm{km}^{2}$ with an areally weighted average of 56 $\mathrm{Mg} / \mathrm{km}^{2}$.

All 10 basins had relict gullies that had probably been active in the 1930's. The presence of rank vegetation on previously unstable areas suggests that the gullies have been relatively inactive during recent years. Further, sediment accumulation in the reservoirs tended to be silty, which suggests an origin from upland loessial soils.

\section{SEDIMENT DELIVERY RATIOS, 1962-75}

The ratios between measured sediment yields and computed upland erosion suggest that sediment delivery ratios (SDR) range from about 2 to 18 percent with an average of about 8 percent (table 5). That is, only about 8 percent of material calculated to have been eroded since 1962 has been transported to the sediment-storage areas provided by the reservoirs. Much of the eroded material was deposited as colluvium in grass and weeds at the lower end of fields and in grassed waterways. Also, steep slopes between most fields and stream channels are heavily wooded. Sediment-laden overland flow which infrequently flows into these forests is usually rapidly infiltrated, 


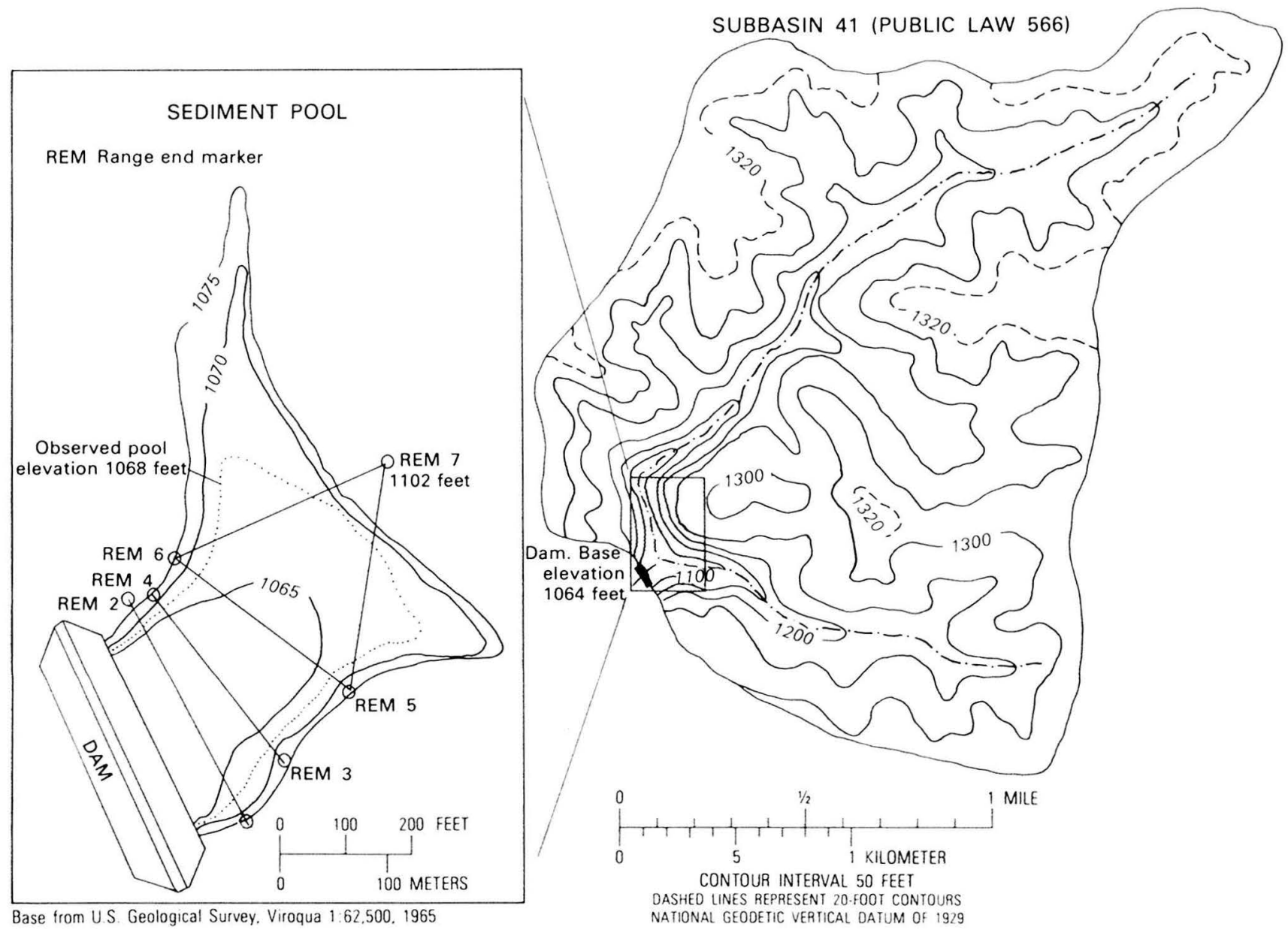

FIGURE 8.-Map showing subbasin 41.

TABLE 5.-Sediment-survey data, Coon Creek basin, 1962-75: sediment accumulated in 10 flood-retarding reservoirs constructed under Public Law 566 (compiled from Lund, 1976). Locations of reservoirs shown in figure 1.

\begin{tabular}{|c|c|c|c|c|c|c|c|c|c|c|c|}
\hline \multirow[t]{2}{*}{ Subbasin } & \multirow{2}{*}{$\begin{array}{l}\text { Length } \\
\text { of record } \\
\text { (years) }\end{array}$} & \multirow{2}{*}{$\begin{array}{c}\text { Trap } \\
\text { efficiency } \\
\text { (percent) }\end{array}$} & \multicolumn{2}{|c|}{ Drainage area } & \multicolumn{2}{|c|}{$\begin{array}{l}\text { Total } \\
\text { sediment yield }\end{array}$} & \multicolumn{2}{|c|}{ Annual sediment yield } & \multicolumn{2}{|c|}{$\begin{array}{l}\text { Calculated annual erosion rate } \\
\text { for } 1975 \text { (table 6) }\end{array}$} & \multirow{2}{*}{$\begin{array}{c}\text { Sediment } \\
\text { delivery rate } \\
\text { (percent) }\end{array}$} \\
\hline & & & & & $(\mathbf{M g})$ & (Tons) & $\left(\mathbf{M g} / \mathbf{k m}^{\mathbf{2}}\right)$ & $\left(\right.$ Tons $/ \mathrm{mi}^{2}$ ) & $\left(\mathrm{Mg} / \mathrm{km}^{2}\right)$ & (Tons/mi ${ }^{2}$ ) & \\
\hline 14 & 13 & 92 & 1.74 & 0.67 & 761 & 839 & 34 & 97 & 690 & 2,000 & 4.9 \\
\hline 15 & 13 & 92 & 3.07 & 1.19 & 1,240 & 1,370 & 31 & 88 & 650 & 1,900 & 4.8 \\
\hline 16 & 13 & 93 & .86 & .33 & 1,260 & 1,390 & 113 & 322 & 870 & 2,500 & 13.0 \\
\hline 17 & 13 & 92 & 2.95 & 1.14 & 600 & 661 & 16 & 46 & 580 & 1,700 & 2.8 \\
\hline 41 & 13 & 93 & 6.07 & 2.34 & 4,090 & 4,510 & 52 & 148 & 860 & 2,500 & 6.0 \\
\hline 23 & 14 & 91 & 3.64 & 1.41 & 430 & 474 & 8 & 23 & 420 & 1,200 & 1.9 \\
\hline 24 & 12 & 91 & 2.21 & .85 & 1,230 & 1,360 & 46 & 131 & 1,100 & 3,100 & 4.2 \\
\hline 25 & 14 & 93 & 3.58 & 1.38 & 3,770 & 4,160 & 72 & 214 & 610 & 1,700 & 12.3 \\
\hline 33 & 15 & 93 & 4.99 & 1.93 & 3,790 & 4,180 & 51 & 146 & 670 & 1,900 & 7.6 \\
\hline 53 & 12 & 93 & 2.66 & 1.03 & 4,180 & 4,610 & 131 & 374 & 730 & 2,100 & 17.9 \\
\hline \multicolumn{7}{|c|}{ Area-weighted average } & 56 & 160 & 720 & 2,100 & 7.8 \\
\hline
\end{tabular}

'Trap efficiency is the estimated percentage of total sediment yield that is caught yields at these sites are adjusted with the appropriate trap efficiency supplied by the Soil behind the dam structure, the rest going through the spillway and downstream. Sediment Conservation Service, Madison, Wis. 
leaving the sediment as colluvium. Such deposits are extensive in Driftless Area forests (R. S. Sartz, oral communication, 1974).

\section{SEDIMENT YIELDS IN SMALL RESERVOIRS, ABOUT 1936-45}

Unlike the situation in the present period, there are not good records of sediment yields from small watersheds for the 1930's and early 1940's. Although many small reservoirs, detention structures, and debris dams were built in that period, we found no recorded surveys of original capacity that would have given us baseline data for computing sedimentation rates from later resurveys. Hence, we had to reconstruct original reservoir capacities. This was done by stratigraphy from borings and dug pits, dendrochronology, photogrammetry, and detailed topographic surveys. The possibility of reconstructing the original capacities was the first criterion for selection of sites. Other criteria were (1) the ability to date the accumulation so as to establish rates and (2) a ratio of capacity to drainage area large enough to trap a major portion of the sediment delivered to the reservoir. Five reservoirs met these criteria and were included in the study (fig. 1 , table 6). Two of the basins (sites 1 and 4) are located in the Coon Creek basin; three (sites 2, 3, and 5) are outside the basin in the Driftless Area.

Whereas the 1962-75 reservoir data are probably accurate within 10 percent, the older records are probably not as accurate for reasons which include very different environmental conditions among sites, very uncertain trap efficiencies, and our ignorance of volume of above-spillway sediment deposited after the reservoir filled to spillway level, bulk density of deposits, the exact original reservoir configuration, and the exact time required for filling.

The different environmental conditions among basins include greatly different basin sizes, basin slopes (expressed as relief-length ratios, table 6), and types of erosion. All sites except site 4 include significant gully erosion, and gully erosion appears to have been most important at sites 2,3 , and 5 .

Trap efficiency is the greatest uncertainty. Although trap efficiency at all sites except No. 5 was high at first [perhaps as high as $60-80$ percent according to the Brune (1953) method], the values declined as the pools filled. Because we did not know the trap efficiencies, we could not correct for them, as we did for the period 1962-75, and our rates may be underestimated.

Even after the pools were completely filled to spillway level, coarser sediment was still deposited above the spillway level on the lessened slopes of the filled ponds. That is, even though a reservoir may have been reported to have been filled to spillway level by a certain date, above-spillway deposits continued to accumulate slowly for some time thereafter. These deposits are present at all sites, but we were able to adjust for this effect at sites 1 and 4 by dendrochronology and eyewitness accounts. At sites 2, 3, and 5, the above-spillway deposits are included in the rates, and thus the rates partially reflect accretion above the spillways. However, the above-spillway deposits probably do not completely offset the underestimate caused by unknown trap efficiencies.

The reservoir deposits (except those at site 4) were poorly sorted. The sediment at site 4 is loessial silt, compacted by grazing, and we measured its bulk specific gravity as 1.4. At the other sites, dug pits

TABLE 6.-Accumulation of sediment in five small reservoirs, about 1936-45 (locations shown in fig. 1), given in order of decreasing dependability of data.

\begin{tabular}{|c|c|c|c|c|c|c|c|}
\hline \multirow{2}{*}{$\begin{array}{l}\text { Site } \\
\text { No. }\end{array}$} & \multirow{2}{*}{$\begin{array}{l}\text { Site } \\
\text { name }\end{array}$} & \multirow{2}{*}{$\begin{array}{c}\text { Period } \\
\text { of } \\
\text { accumulation }\end{array}$} & \multicolumn{2}{|c|}{ Drainage area } & \multirow{2}{*}{$\begin{array}{l}\text { Relief- } \\
\text { length } \\
\text { ratio }\end{array}$} & \multicolumn{2}{|c|}{ Annual sediment yield } \\
\hline & & & $\left(\mathrm{km}^{2}\right)$ & $\left(\mathrm{mi}^{2}\right)$ & & $\left(\mathrm{Mg} / \mathrm{km}^{2}\right)$ & (Tons/ $\left./ \mathrm{mi}^{2}\right)$ \\
\hline 1. & Clement SCS Dam - & $\begin{array}{r}1936-42 \\
(6 \mathrm{yr}) .\end{array}$ & 5.45 & 2.10 & 0.040 & 4,400 & 13,000 \\
\hline 2. & Upper Michell Dam--------- & $\begin{array}{r}1941-45 \\
(4 \mathrm{yr}) .\end{array}$ & .23 & .09 & .126 & 5,400 & 15,000 \\
\hline 3. & Bischell Debris Dam-- & $\begin{array}{r}1937-39 \\
(2 \mathrm{yr}) .\end{array}$ & .28 & .11 & .189 & 14,000 & 40,000 \\
\hline \multirow[t]{3}{*}{4.} & Johnson CCC Dam --_------ & $\begin{array}{r}1936-77 \\
(41 \mathrm{yr})\end{array}$ & .28 & .11 & .034 & 1,100 & 3,000 \\
\hline & & $\begin{array}{r}1936-62 \\
\text { (26 yr calc) }\end{array}$ & .28 & .11 & .034 & 1,600 & 4,600 \\
\hline & & $\begin{array}{r}1936-40 \\
(4 \mathrm{yr} \text { calc). }\end{array}$ & .28 & .11 & .034 & 2,500 & 7,000 \\
\hline 5. & Middle Michell Debris Dam-- & $\begin{array}{r}1941-43 \\
(2 \mathrm{yr}) .\end{array}$ & .08 & .03 & .205 & 2,500 & 7,000 \\
\hline \multicolumn{3}{|c|}{ Area-weighted average } & -- & --- & $-\infty$ & 4,800 & 14,000 \\
\hline
\end{tabular}


revealed large boulders (up to $80 \mathrm{~cm}$ mean diameter) in matrices composed of particles ranging from clay to small boulders. There is little pronounced stratification, but the general trend in eight dug pits, ranging in depth from 2 to $4 \mathrm{~m}$, is for increasingly fine material toward the surface. Boulders (30-60 $\mathrm{cm}$ mean diameter) were found in the lower half whereas the surface 0.3$0.5 \mathrm{~m}$ was mostly silt and fine sand. We interpreted this as reflecting the decrease with time of extremely high runoff peaks and concomitant reduction of erosion and sediment load. Except at site 4, there was a decrease of particle size towards the dam. As a result, it was difficult to determine bulk specific gravities of these heterogeneous mixtures. On the basis of samples of the finer materials, we estimate a bulk specific gravity of about 1.4 for all sites except 5 . Site 5 had more large rocks than the others, so we estimated a bulk specific gravity of 1.9 .

The final uncertainty is the exact time required to fill the reservoirs. Because the times were short (about 2 years at sites 3 and 5), a small error in time could be critical. For inclusion of a site, we required at least one reliable witness and we tried to obtain corroboration. For example, this was done by dendrochronology at site 1 , where an age-dated willow tree near the dam at spillway level verified the information given by a local witness, a 92-year-old man, to the exact year.

At site 4, we measured the entire deposition from 1936 to 1977 and budgeted that over time to get shorter-term rates (fig. 9). Site 4 is important because the erosional debris, all fine textured, came primarily from sheet and rill erosion on upland slopes, mostly cultivated land, whereas the other four sites had considerable gully erosion in addition to upland sheet and rill erosion. The total sediment deposited since 1936 at site 4 was about $12,300 \mathrm{Mg}$ (13,600 tons), giving an overall 1936-77 annual rate of $1,100 \mathrm{Mg} / \mathrm{km}^{2}$ (fig. 9). However, annual sediment yields from upland erosion for the period 1962-75, as measured in our 10 basins, ranged from 8 to $131 \mathrm{Mg} / \mathrm{km}^{2}$. If we apply the maximum annual value obtained from those basins $\left(131 \mathrm{Mg} / \mathrm{km}^{2}\right)$ to site 4 for the same period, we can then rebudget the remainder of the sediment for the period 1936-62 giving an adjusted rate for that period of $1,600 \mathrm{Mg} / \mathrm{km}^{2}$. We then smooth the curve to give continuity and insure that the mass volumes are equal (that is, area [volume] $A=$ area [vol.] $A^{\prime}$ and $B=B$ ). The shape of the curve is thus determined by the number of constraints imposed. There are three lines of evidence which support continuous sedimentation and justify a smooth curve. The first is historical: the rapid sedimentation rates of the 1920's and 1930's are within the memory of many area farmers. Average vertical accretion rates of that period were about $15 \mathrm{~cm}$ per year, and this was usually from several events. Although a single event could bring enough sediment to bury the grass cover of the flood plain, aggradation was usually more insidious so that fence posts seemed to shrink in height over a period of time. Second, detailed precipitation data from the Coon Creek basin for the years 1934-40, when sedimentation rates were at the highest, show no extreme daily events (Soil Conservation Service, 1942). However, extreme events $(>20 \mathrm{~cm} / \mathrm{d})$ did occur in 1951 and 1978 without the high sedimentation rates which occurred in the 1920's and 1930's. Third, superimposition of six continuous sedimentation graphs (figs. 10, 11) indicates that the curves are remarkably similar (these data will be developed later in this study). Because the times of observation are different in each of the six graphs, the similarity would be highly improbable unless the rates were generally continuous. The curves should be considered as trend lines and may not be correct for any given year. The curves can be integrated to yield composite curves (fig. 11).

Figure 9 indicates that annual sediment yield rates from upland erosion alone during the period 1936-40 may have been well over $2,400 \mathrm{Mg} / \mathrm{km}^{2}$. This figure compares well with that obtained by the USLE for 1934 of about $3,000 \mathrm{Mg} / \mathrm{km}^{2}$ and probably reflects the more efficient offsite transport of sediment through the rills and upland gullies of that period. If sediment yields from upland sheet and rill erosion were as high as indicated at site 4 , then overall annual sedimentation rates, including valley trenching, of $4,000-5,000$ $\mathrm{Mg} / \mathrm{km}^{2}$ (as found, for example, at site 1, fig. 12) appear to be reasonable.

The small reservoir sites for the period 1936-45 are subjectively ranked in order of data dependability (1-5, table 6). Given the trap efficiency problem, the estimated sedimentation rates are probably low. We have no way of testing the values statistically, but we believe that they are all correct within the bounds of -25 percent and +50 percent. Despite the uncertainties, the sediment yields for the period are remarkably consistent with a maximum/minimum range of 5.5 times, while the ostensibly better 1962-75 data have a variation of 15 times. Although the value for any one site may be imprecise, the errors may well be partially compensating. We believe the overall annual areally weighted average of $4,800 \mathrm{Mg} / \mathrm{km}^{2}$ is a reasonable value for Coon Creek basin and for much of the Driftless Area during the 1936-45 period.

\section{SEDIMENT DELIVERY RATIOS, ABOUT 1936-45}

The weighted yield of $4,800\left(\mathrm{Mg} / \mathrm{km}^{2}\right) / \mathrm{yr}$ (table 6 , fig. 12) was about 60 percent greater than the average upland erosion calculated for the 10 subbasins in 1934 and about 30 percent greater than the highest value. 


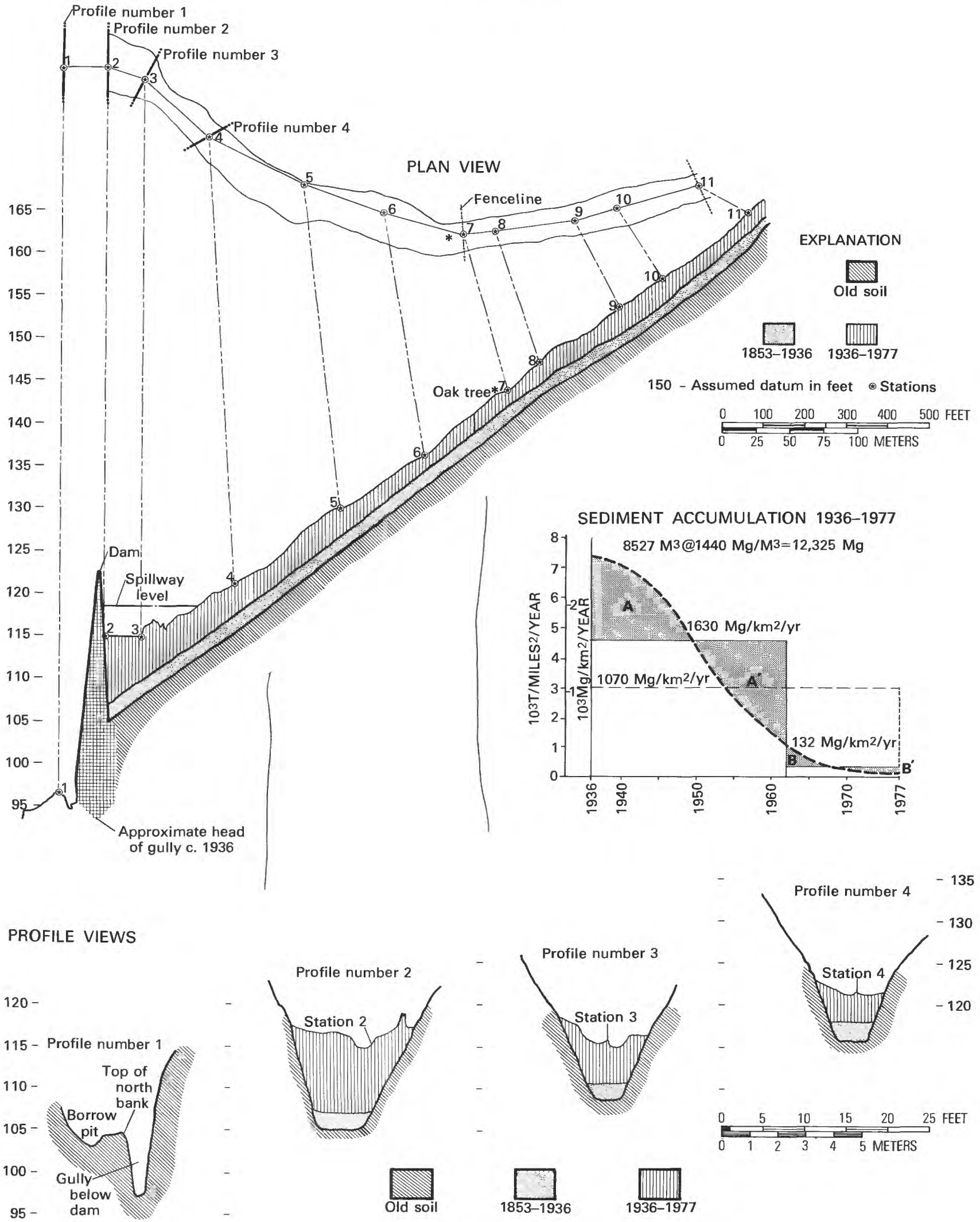

FIGURE 9.-Map and diagram showing sediment accumulation in the Johnson Civilian Conservation Corps dam reservoir. Detailed location in figure 1. 

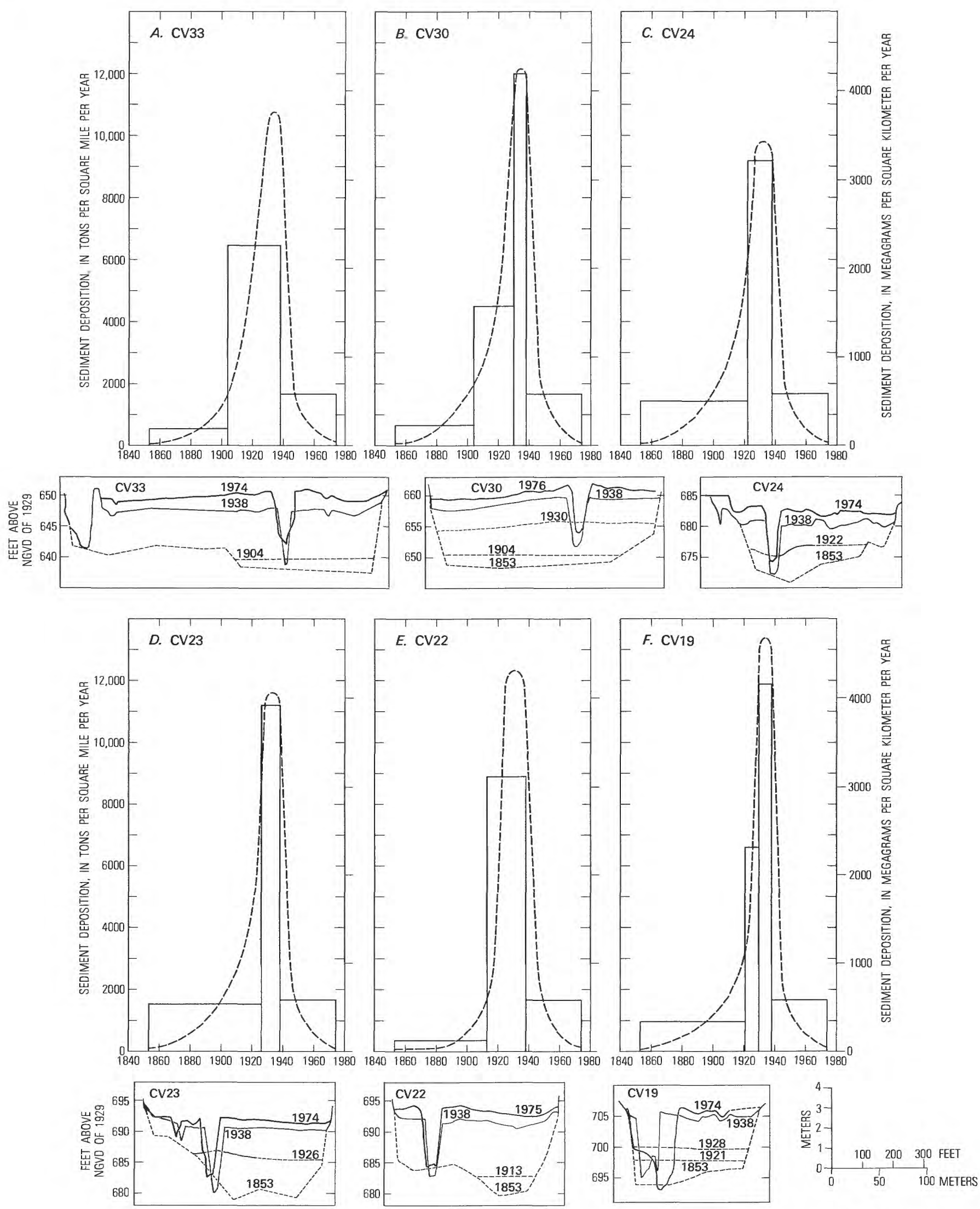

FIGURE 10.-Diagram showing sediment deposition rates at selected valley sites in Coon Creek basin, 1853-1977. 


\section{QUANTITY OF MODERN OVERBANK SEDIMENT c. 1853-1938}

Distribution shown by width proportional to cross-section area of sediment deposits

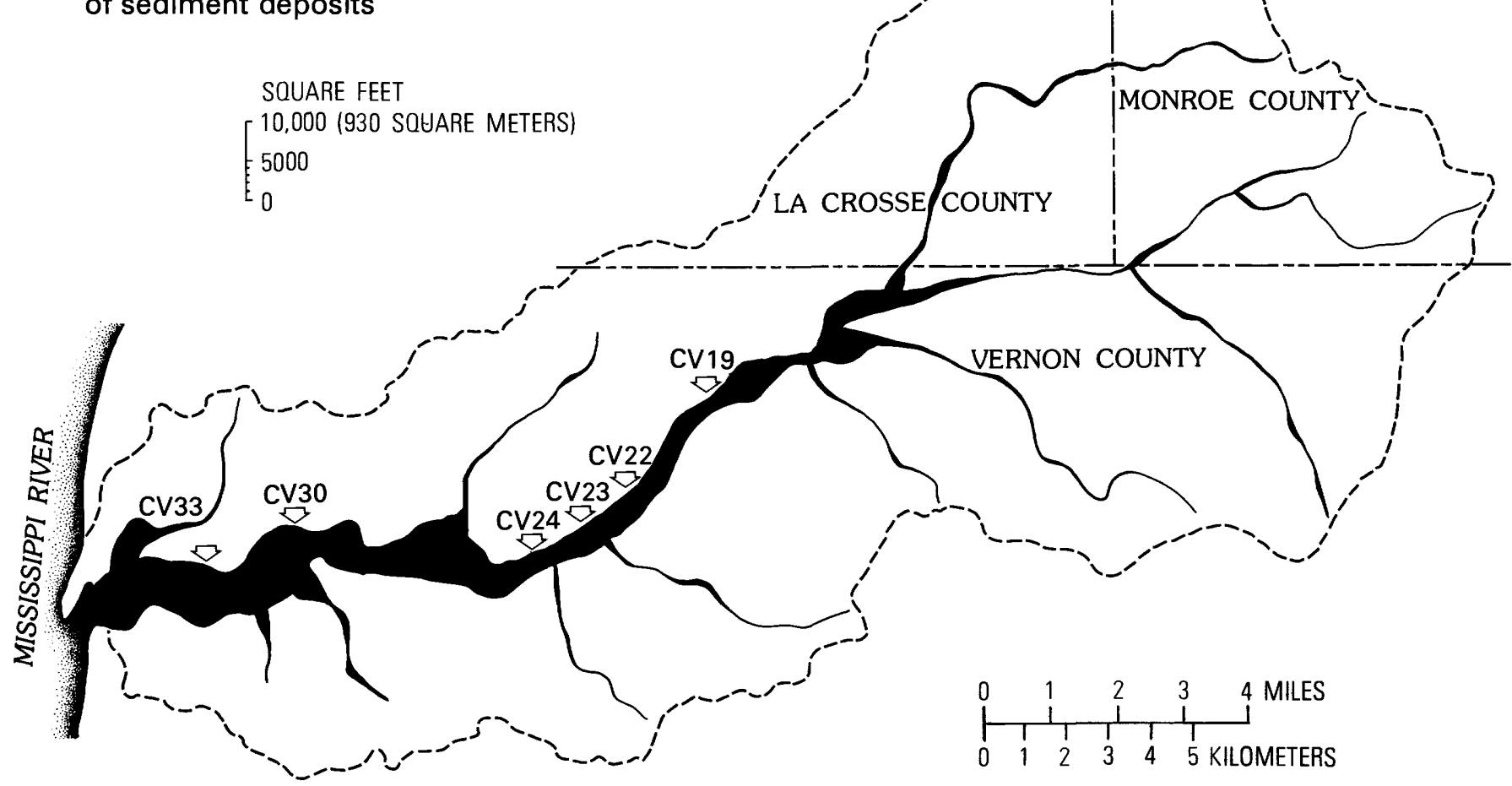

Figure 10.-Continued

Given the low SDR's of the present, the observation that sediment yields for small basins in the 1930's were apparently greater than upland sheet erosion rates is somewhat surprising. However, at least three phenomena appear to explain this disparity. First, the upland was locally riddled with gullies, many of which extended down through the woods to the stream channel (figs. 2 and 3). Not only would these gullies have greatly increased erosional debris, but the possibility of colluvial deposition was greatly diminished, thus permitting much of the erosional debris from upland fields to reach the stream channel. Second, tributary stream channels were themselves rapidly becoming trenched in the late 1930's (McKelvey, 1939, p. 41-43; Happ and others, 1940, p. 52). Third, a sandy high terrace in the lower ends of some valleys tributary to the lower half of the Coon Creek basin was being rapidly eroded at that time (as at site 1, for example; such erosion no doubt made a significant contribution to the observed rate of sediment accumulation in the lower valley).

\section{SEDIMENT DEPOSITION RATES IN THE MAIN VALLEY, 1853-1976}

The Coon Creek basin was selected for this study in part because an earlier study of valley morphology had been done in 1938-39 (McKelvey, 1939). Detailed surveys were made of sediment accumulation on the flood plains and the values were recomputed in 1975 (Trimble, 1976a). In the mainstream valley, most of this material was deposited by vertical accretion, but in the tributaries, lateral accretion was almost as important. Of the total volume of modern sediment measured in the Coon Creek basin, vertical accretion accounted for 93 percent and lateral accretion was only 7 percent. Even in tributaries, vertical accretion was more important than lateral accretion (Trimble, 1976a, p. 103, 107). During the period 1853-1938, sediment deposition was $19.5 \times 10^{6} \mathrm{~m}^{3}$ from an area of $365 \mathrm{~km}^{2}$ (Trimble, 1976a, p. 103). This is a net total value; that is, the estimated volume of material eroded from tributary channels has been subtracted. At an assumed average bulk specific gravity of 1.4 , the overall annual rate of deposition averaged about $920 \mathrm{Mg} / \mathrm{km}^{2}$ between 1853 , the time of European settlement, and 1938. From 1938 to 1975 the annual rate of deposition was about 40 percent of the earlier rate, or about $370 \mathrm{Mg} / \mathrm{km}^{2}$. This valley sediment may represent more than 80 percent of all eroded material reaching the streams, only a small proportion being transported out of the basin by the stream as basin efflux or sediment yield (Trimble, $1976 \mathrm{~b}$, in press). 


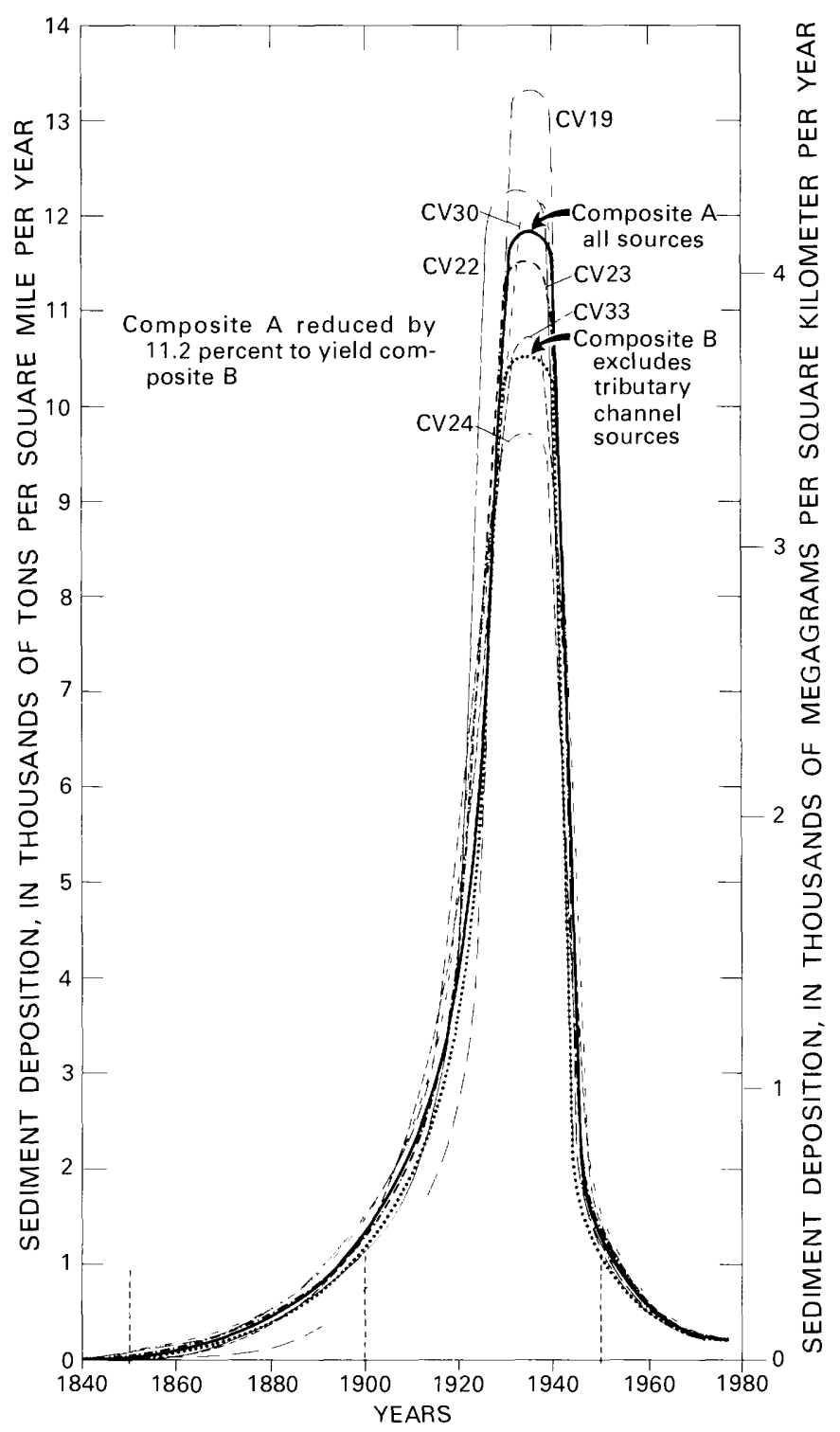

FIGURE 11.-Composite curve of sediment deposition for the main valley of Coon Creek basin, 1853-1975.

Of the fluvial sediment stored in the Coon Creek basin from 1853 to 1938 , about 75 percent was in the main valley. Although deposition rates in tributaries may have been somewhat different than in the main valley, for the purpose of budgeting sediment deposition we have assumed them to be about the same; error introduced by this assumption is probably minor at the basinwide scale. We established differential rates of deposition through time (fig. 10) by using buried cultural features such as roads, bridges, fences, and buildings, all of which could be dated.

The profile at range CV30, located in the lower main valley of Coon Creek, serves as a good example (fig. 10B). The 1853 (presettlement) flood plain was located in 1938 by borings to the old alluvial soil, a dark, organic, texturally homogeneous (probably Mollic) soil. The approximate elevation of the 1904 flood plain, about $0.75 \mathrm{~m}$ above that of 1853 , shows a rate of only $0.015 \mathrm{~m}$ per year of vertical accretion during the first 51 years of settlement. The 1904 elevation was approximated by finding the compacted flood plain surface behind a railroad embankment which had acted as a dike, allowing flood-plain aggradation on the stream side but eventually creating a lake between the dike and the adjacent hillside. The elevation thus approximated is probably a maximum value. By 1930 , the flood plain had aggraded by another $1.5 \mathrm{~m}$ (or $0.06 \mathrm{~m}$ per year), a remarkable increase over the previous rate. The 1930 flood-plain elevation was established by locating and boring to an old gravel road which crossed the stream at a local bridge, the abutments of which have been completely buried. The existence of the road, the year of abandonment (1930), and the fact that the road was at the level of the flood plain were disclosed by elderly local residents. Of interest is the fact that within $3 \frac{1}{2}$ years of abandonment, the road was completely covered by sediment and not detectable on an aerial photograph made in early 1934 . The 1938 profile was a surveyed line. In the 8 years following 1930 , the flood plain aggraded almost $1.2 \mathrm{~m}$ (or $0.15 \mathrm{~m}$ per year), indicating the massive sedimentation occurring during the 1930 's. Then, in the 38 years between 1938 and 1976 , there was only $0.6 \mathrm{~m}(0.016 \mathrm{~m}$ per year) of aggradation, a greatly reduced rate.

The deposition rates for the discrete periods above were established from the area (and hence relative volume) of accretion shown in the cross-sectional profile (fig. 10B). There is enough information here to draw a smoothed line describing the differential rates of sediment deposition through time, but the line can be improved with more definite end values derived as follows.

We know that erosion and sediment deposition rates were low at the time of European settlement from the following evidence:

(1) Minimal upland erosion.-We infer that the deep, well-structured forest and prairie soils probably had enough infiltration capacity for all but the greatest precipitation intensities and amounts. Thus, most stormflow would have been subsurface flow (largely throughflow) (Ward, 1975, p. 247) with surface stormflow generally restricted to channel areas. Research in the region has shown that relatively undisturbed forest and grasslands generally have little surface stormflow and practically no erosion. Sartz (1976, p. 130) estimates a 13-year sediment yield of 


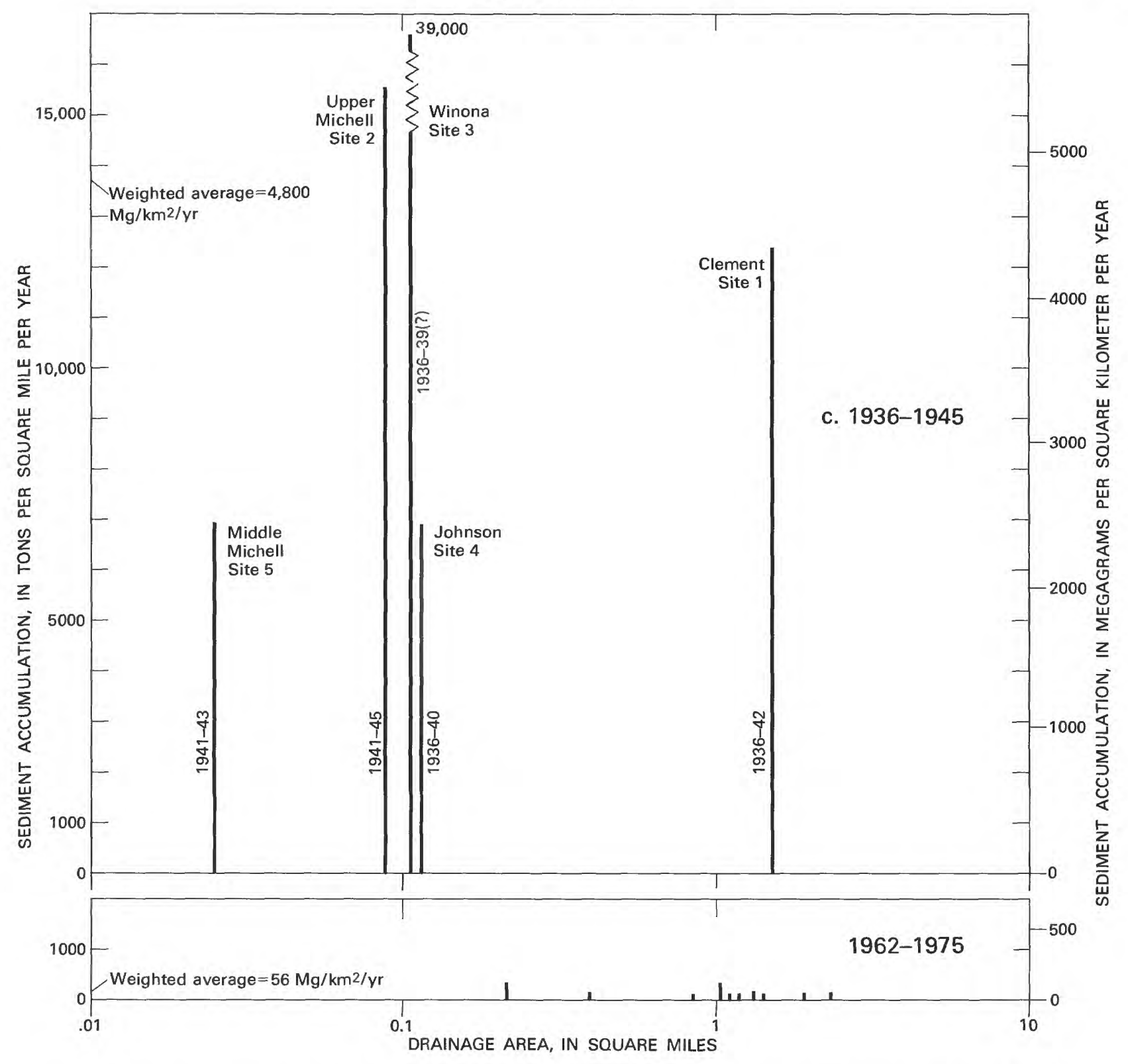

FIGURE 12.-Diagram showing sediment accumulation in small reservoirs of the Driftless Area, about 1936-45 and 1962-75.

$0.02 \mathrm{Mg} / \mathrm{km}^{2}$ annually from a wooded area which formerly had been affected by grazing. Many tributary watersheds of over $1 \mathrm{~km}^{2}\left(0.39 \mathrm{mi}^{2}\right)$ had no stream channels at the time of European settlement, indicating the low surface runoff at that time. Concerning channel erosion in perennial streams, early literature indicates stable stream banks (for example, Owen, 1847, p. $35,37,58$ ) and photographs indicate that these channels were stable in some areas until after 1900 (fig. 13).

(2) Small stream-sediment loads.-Early explorers of the region, including scientists, uniformly praised the clarity of the streams. One report even described the stream bottom as seen several feet beneath the surface (Owen, 1847, p. 35, 37, 58). Streams were inhabited by brook trout, which are very intolerant of suspended sediment (Trowbridge, undated, p. 19). Early Army Engineer reports indicate that the upper Mississippi River was clear enough in the 1860 's so that stream bottom dune formations and vegetation could be easily observed (U.S. House of Representatives, 1867, p. 11, $17,59,61$ ). In 1867 , about 15 years after settlement, a flood of 3-year frequency on the Mississippi River downstream at Keokuk, Iowa, had a sediment concentration of only 100 parts per million (U.S. Army Corps of Engineers, 1867, p. 321). These observations suggest 
that stream sediment loads were quite low by present standards.

(3) Flood-plain soils.-As already noted, the presettlement flood plains were generally covered with a dark, well-developed Mollisol of fairly uniform, loamy texture. The widespread presence of this soil indicates stable conditions for a long period preceding European settlement and seems to preclude rapid vertical accretion and bank cutting and accompanying lateral accretion.

(4) Carbon-14 dates in older alluvium.-In the Kickapoo River, adjacent to Coon Creek, Johnson (1976, p. 132; written communication, 1976) has established a date of about $2445 \pm 60$ years before present at $0.75 \mathrm{~m}$ below the surface of the old flood-plain soil. Other carbon-14 dates obtained by Johnson gave similar rates of vertical accretion. If we transfer the above value to Coon Creek using the cross-sectional profile at range CV30 (fig. 10B), the annual rate of deposition would have been approximately $10 \mathrm{Mg} / \mathrm{km}^{2}$ of material from the total drainage area. The exact value is not as important as the fact that the value is extremely low relative to the rates after agricultural activity.

The rate of deposition for recent years can be definitely ascertained only after a few more years when resurveys can be made of the profiles. Deposition on flood plains has been slow in recent years, as shown by such evidence as lack of aggradation around fence posts and root crowns of trees, but these observations do not yet give good quantitative data. However, surveys of the reservoirs constructed under Public Law 566 give us a reasonable estimate of eroded material delivered downstream to tributary flood plains where the dams are located: this material is the maximum net amount from upland sources available for deposition on the flood plains in valleys not controlled by Public Law 566 reservoirs. Of this material, which amounts to $56 \mathrm{Mg} / \mathrm{km}^{2}$ annually (table 5), an unknown proportion is deposited on downstream flood plains during the now-infrequent floods, and the remainder is transported out of the system by the stream as sediment discharge. The determination of the proportion transported from the basin is complicated by the channel erosion occurring in tributaries and in the upper main valley. Of course, channel erosion is primarily a reworking of existing sediment deposits, and any material later deposited downstream in the channel or on the flood plain cannot be considered a net addition. However, assuming that the annual rate of delivery of sediment $\left(56 \mathrm{Mg} / \mathrm{km}^{2}\right)$ to the 10 small reservoirs is representative of the basin as a whole places an upper limit on net addition to sediment storage.

Using the beginning and end points derived above, we can now draw smoothed curves indicating differential deposition rates through time (fig. 10).

The sediment accumulation rate at each of the six main valley sites is used to budget all sediment identified in the Coon Creek basin, and the areal base is the entire basin, not just the upstream tributary area. This uniform areal base allows integration of the values from various locations so that composite curves can be drawn. The indicated peaks, all in the 1930's and early 1940 's, range from $3,500 \mathrm{Mg} / \mathrm{km}^{2}$ at range CV24 to $4,700 \mathrm{Mg} / \mathrm{km}^{2}$ at range CV19. Because so many uncertainties exist in reconstructing such rates, the variation among sites is probably insignificant and only a mean or composite value is useful. The individual rates
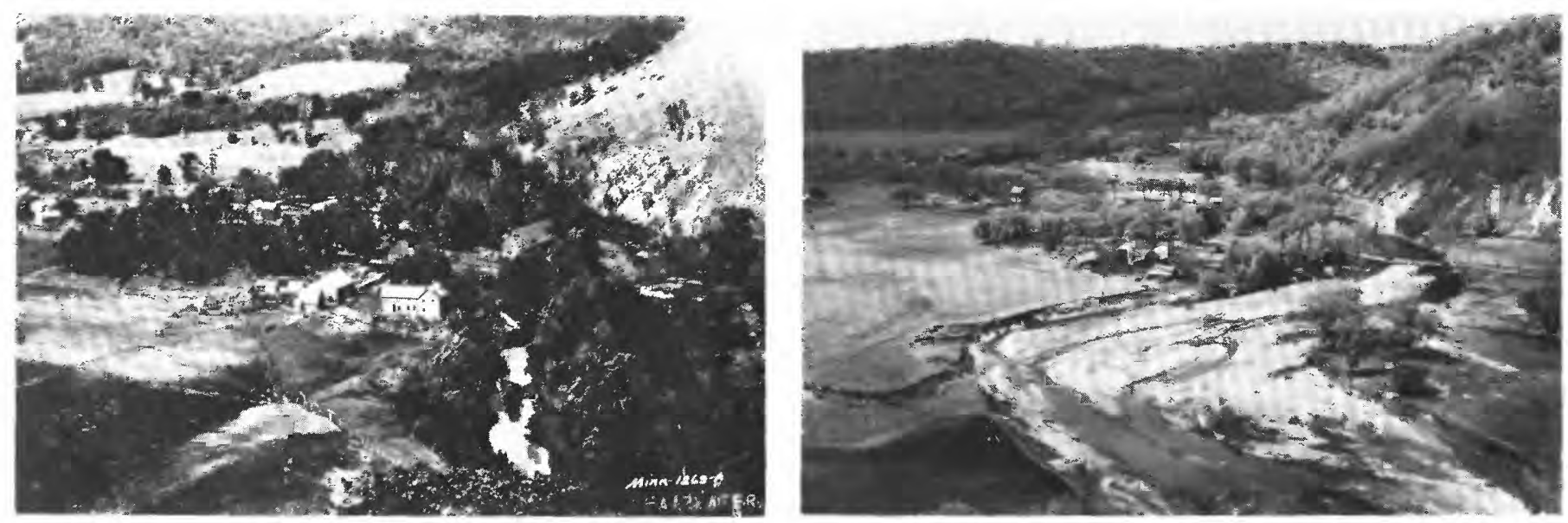

FIGURE 13.-Photographs showing bank and channel erosion of perennial tributaries. A, Near Fairwater, Minn., on the North Fork of the Whitewater River, a Driftless Area stream similar to Coon Creek, about 1905. Note vegetation growing close to water's edge on apparently stable banks of relatively narrow stream. $B, 1940$, Note that stream has widened by a factor of several times and now has a braided configuration. Photographs by USDA Soil Conservation Service. 
have been superimposed and a composite drawn (fig. 11). Given the difficulties and uncertainties of reconstructing such rates, there is remarkable coincidence of the six graphs. The composites indicate that the highest rates existed between 1920 and 1945; the rates peaked in the decade of the 1930's. Composite B is the most meaningful because the sediment estimated to have come from tributary channel erosion (Trimble, 1976a) has been excluded from the budget. This peak of about $3,700 \mathrm{Mg} / \mathrm{km}^{2}$ is relatively similar to the weighted values of $4,800 \mathrm{Mg} / \mathrm{km}^{2}$ measured in reservoirs during about the same period (table 6 , fig. 12). We therefore conclude that the average annual net rate of sedimentation on the flood plains was over 3,500 $\mathrm{Mg} / \mathrm{km}^{2}$ in the 1930's, while the rate for recent years appears to be on the order of $35-70 \mathrm{Mg} / \mathrm{km}^{2}$. This means that the current net sedimentation rate is on the order of about 1 or 2 percent of that existing in the 1930's.

\section{RELATION OF EROSION AND SEDIMENTATION TO LAND USE AND MANAGEMENT}

An objective of this study is to relate erosion and sedimentation to land use. A major problem is that while we have reconstructed a continuous record of sedimentation in the main valley, we do not have a similar record for erosion on upland agricultural fields.

We have reconstructed erosive land use (the erosive potential of land use) from the graph of historical land use (fig. 5). To do this, each type of land use was weighted by an erosive factor proportional to the management involved (Trimble, 1974, p. 6-8). These factors are a combination of the vegetative cover $(C)$ and management practices $(P)$ factors of the USLE discussed previously, and they change over time (table 7). We have assumed that management changed little from the time of settlement to the 1930 's, when modern conservation measures were introduced.

These management-cover factors are clearly estimates, and changes in them would change our estimate of erosive land use (fig. 14). The values given are

TABLE 7.-Management-weighting factors used to estimate erosive land use, 1853-1974

\begin{tabular}{|c|c|c|c|c|}
\hline Land use & $\begin{array}{c}1853- \\
1930 \\
\end{array}$ & 1940 & 1950 & $\begin{array}{c}1960- \\
\text { present }\end{array}$ \\
\hline Row crops & 0.45 & 0.32 & 0.26 & 0.20 \\
\hline Small grains -_________ & .20 & .15 & .13 & .10 \\
\hline Hay and pasture- & .04 & .022 & .014 & .005 \\
\hline Farmstead and roads - & .20 & .15 & .13 & .10 \\
\hline Abandoned - & .05 & .045 & .043 & .04 \\
\hline Grazed forest & .03 & .025 & .023 & .02 \\
\hline Ungrazed forest - & .002 & .002 & .002 & .002 \\
\hline Urban - & .05 & .05 & .05 & .05 \\
\hline
\end{tabular}

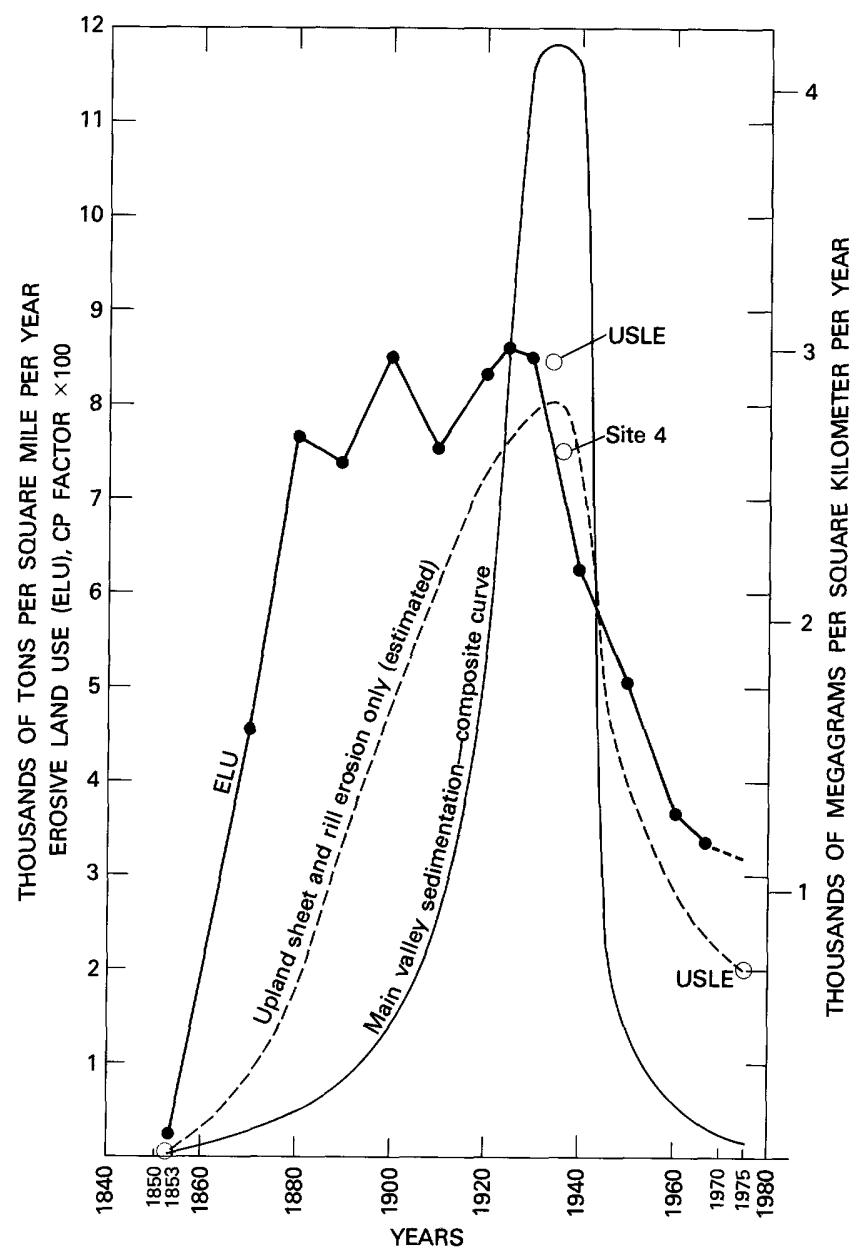

FIGURE 14.-Graph showing erosion, sedimentation, and erosive land use, 1853-1975.

composite values: the percentage of land area in each land use was multiplied by the appropriate factor, the weighted values for each land use were summed for that year, and the sum was multiplied by 100 to give a whole number which is the composite value for the entire area. The decrease of the factors since the 1930's reflects both improvement of individual management practices and the spread of their use.

Erosive land use and main-valley sedimentation rates are graphed as a function of time in figure 14. Additionally, a graph of upland erosion has been sketched based on the data points shown plus the logical deduction that upland erosion was very low before European settlement. All three rates are correlated in a general way, but our analysis suggests a time lag, or hysteresis, in the relationship of erosion and sedimentation to erosive land use. That is, a change in erosive land use did not immediately cause downstream changes of sediment yields, but there appears to have been a lag in the response of erosion and perhaps an even greater 
lag in downstream sedimentation, the latter being related to travel time and temporary storage of sediment en route. Such a lag has long been suspected (Happ, 1944, p. 62-63; Trimble, 1976c; Knox, 1977), but it has not yet been documented.

The data in figure 14 have been transformed to a format which shows erosion and sedimentation as functions of erosive land use (fig. 15). The erratic fluctuations in the graph between 1880 and 1925 are probably due to poor data and their significance is dubious. As would be expected from earlier discussion, erosion and sedimentation behave somewhat differently in response to erosive land use.

In the first three decades of settlement, erosive land use expanded rapidly, causing erosion to increase (probably at a rate that was initially low but exponentially increasing). This was caused in part by (1) expansion of agriculture on increasingly steeper slopes (Trowbridge, undated, p. 19, 51) and (2) gradually increasing depletion, compaction, and degeneration of soil which was originally well structured, high in organic material, and uncompacted and had a high infiltration capacity.
Much of the early (to about 1890) erosion was probably characterized mostly by sheet and rill erosion, usually on discontinuous areas of the few steeper slopes then in cultivation. In many areas, soil was transported no farther than the base of slopes or the lower edge of fields, where vegetation trapped the sediment and allowed much of the water to infiltrate. Additionally, most smaller basins of as much as $1 \mathrm{~km}^{2}$ $\left(0.39 \mathrm{mi}^{2}\right)$ had nearly level valleys that were concave upwards with no channels and supported vegetation which acted as an efficient sediment trap. Thus, much sediment was stored on the slopes and in the shallow draws of the upland.

The progressive erosion of loamy topsoil decreased infiltration, thus further increasing surface runoff. In experimental studies, for example, Borst and others (1945) found that as continuing cultivation had removed $15 \mathrm{~cm}(6 \mathrm{in})$ of soil, the organic content (a determinant of soil structure and infiltration capacity) decreased from over 2.0 percent to less than 0.5 percent. After some period of time, perhaps one to four decades, the combined effects of increasing cultivated area, steeper slopes, soil degeneration, and soil erosion

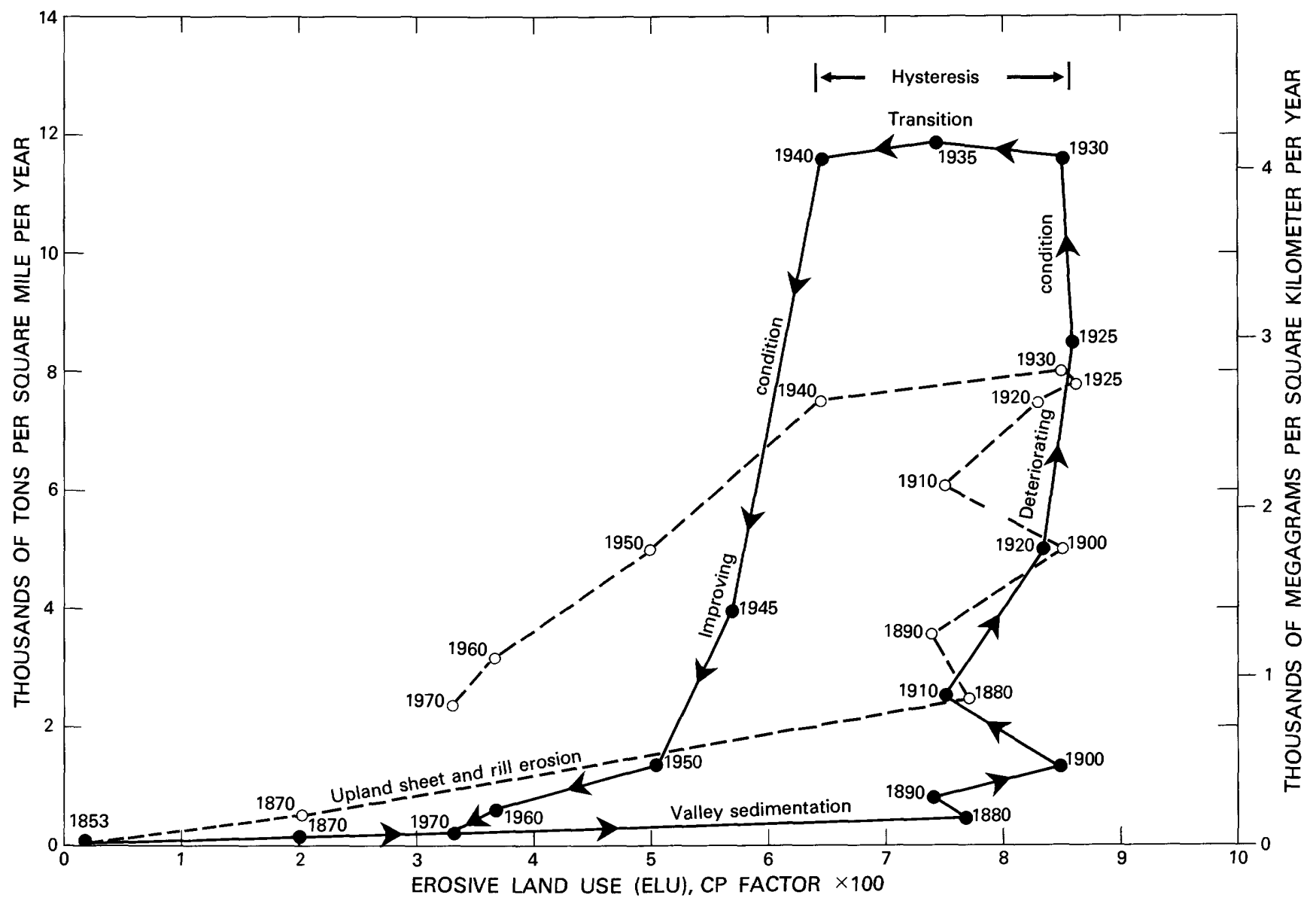

Figure 15.-Diagram showing the relation of erosion and sedimentation to erosive land use, 1853-1975. 
increased, causing overland flow to be of sufficient magnitude to flow uninterrupted across one or more fields, effectively transporting most of the eroded material to preexisting drainageways or channels. This movement of water created a drainage network of rills and gullies across fields that, in turn, increased the magnitude and velocity of surface flow (figs. 2 and 4). In particularly severe cases, the channelized flow sufficiently exceeded the infiltration capacities and erosional thresholds of vegetated strips, meadows, and forest below cultivated fields so that these areas were cut by gullies (Trowbridge, undated, p. 53), many of which dissected previously stored sediment (fig. 16A and $B$ ). By the 1930's Trowbridge (p. 30) could state that "field gullies are common and a whole series from 6 inches to 3 feet deep can form in a field as the result of one hard rain if it occurs in a large field that is devoid of vegetation or in a clean-tilled crop." The gullying not only meant greatly increased sediment loads but allowed delivery of the sediment farther downslope and downstream where much was deposited as storage on the relatively gentle slopes of tributary flood plains and even farther down valley. As storm runoff peaks continued to increase, some upper tributary valleys, including modern sediment deposits, were eroded (trenched), and sediment was transported farther downstream, rapidly aggrading the main valley. This problem was further exacerbated by increased grazing of upland pasture and forest as more cattle had to be accommodated (fig. 17). Perhaps more importantly, the flood-plain pastures, upon which farmers had so long depended, were being frequently flooded by about 1920. The flood danger to the animals plus the deterioration of flood-plain pasture by sediment deposits (fig. 18) forced some farmers to greatly increase upland grazing densities. In Winona County, Minn., a region similar to the Coon Creek basin, about one-fourth of the flood-plain area had been damaged by sediment deposition, primarily sandy material, and had become idle (Brown and Nygard, 1941, p. 15, 18). The grazing of forests decreased infiltration and caused overland flow, damaging the land downslope (Soil Conservation Service, undated, p. 32). For example, Hays and others (1949, p. 36-37) found that ungrazed forests of the

FIGURE 16.-Photographs showing formation and healing of hillside gullies, 1905-78. A, Elba, Minn., a part of the Driftless Area similar to Coon Creek, about 1905. Note forested slopes above town. B, 1940. Note cleared and gullied hillside. Primary source of gullying appears to be the upland field, but the large channel to the left apparently originates on the cleared slope. $C, 1978$. Photograph made 4 weeks after rainstorm which exceeded the 100 -year return frequency $(24 \mathrm{hr})$. Note generally good forested condition and complete lack of gullies. $A$ and $B$ by USDA Soil Conservation Service. $C$ by authors.

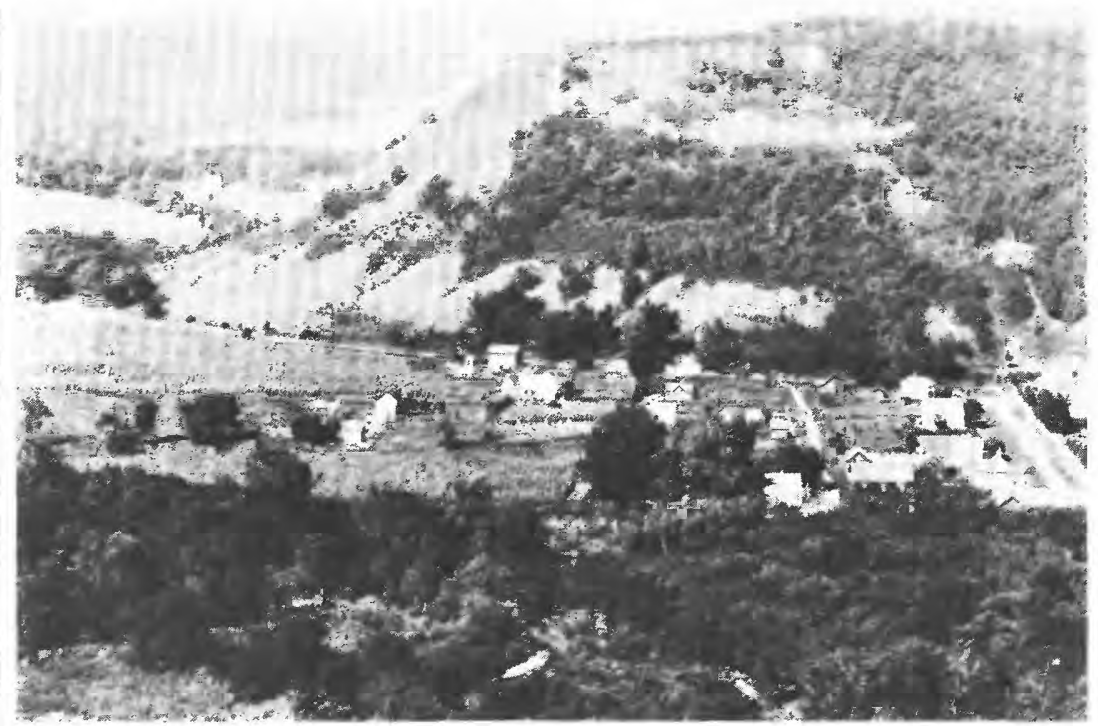

A

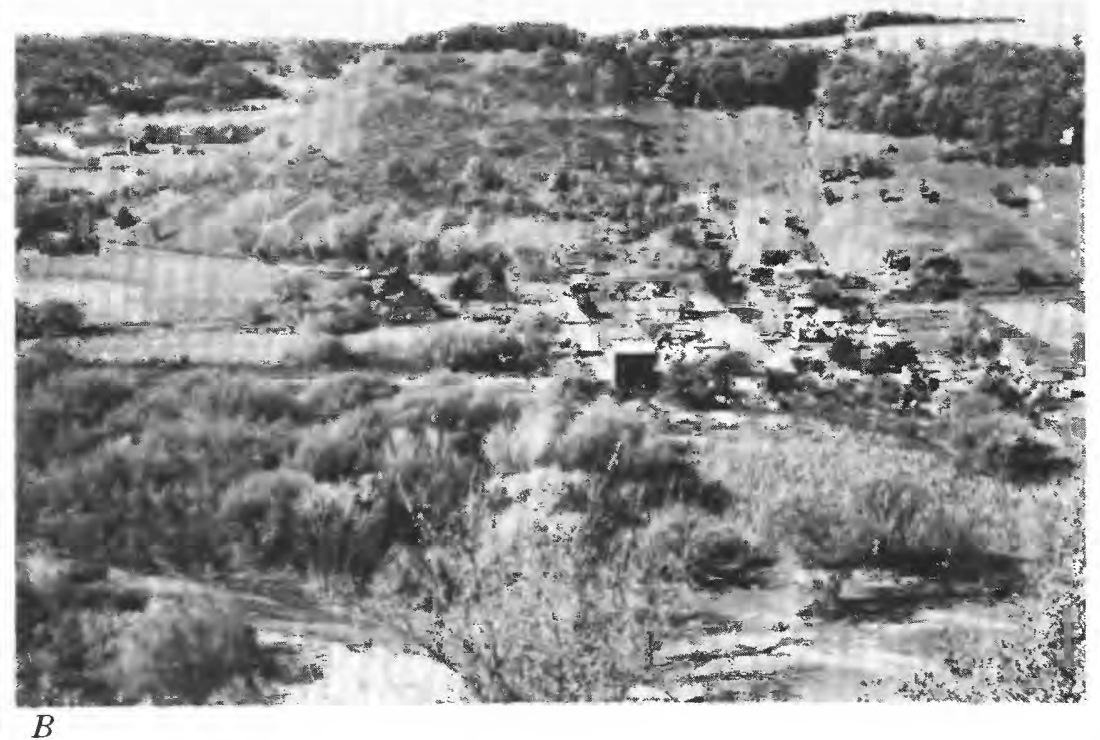

$B$

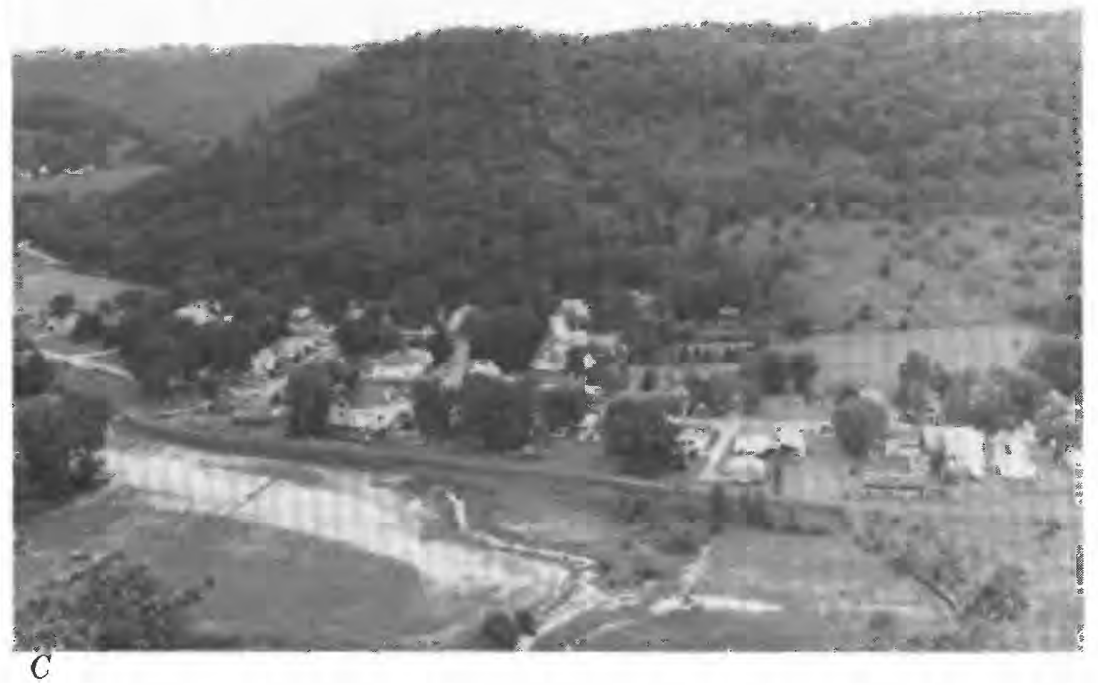


Driftless Area had negligible runoff while grazed forests had about four times that of open pasture and about one-sixteenth that of cultivated land. By the 1930 's, forest was being cleared for pasture on such steep slopes that dislodged boulders actually rolled down the slopes in some cases (Trowbridge, undated, $p$. 33). In general, open pasture was depleted of nutrients, giving poor vegetative cover, and was overgrazed and compacted. The droughts of the early 1930's exacerbated the problem by further weakening the vegetation (Soil Conservation Service, undated, p. 19). The additional runoff peaks from open and wooded pasture caused hillside gullies and increased downstream valley trenching which, by $1920-25$, caused sedimentation rates to exceed the estimated rates of sheet and rill erosion on upland agricultural fields (fig. 14).

If no changes had occurred on the agricultural landscape, erosion and sedimentation would have continued and would have declined only as land became too eroded to cultivate, was abandoned, and slowly reverted to scrub and eventually to forest. However, great improvements in land use were initiated in 1934, consisting of better management and some decreases in area cultivated, especially steep, critical areas (figs. $2-5,7$ ).
Although erosive land use was greatly decreased between 1930 and 1940, a commensurate decrease of erosion did not occur. That is, there was a lag between the implementation of soil conservation measures and a significant decrease of erosion and sedimentation. The reasons are a general reversal of those previously given for a deteriorating watershed. Improvements in soil management may give limited immediate soil improvement. While changes such as terracing, cover crops, and contour plowing may give rapid results, many years of replenishing organic material, implementing good crop rotations, growing cover crops, and restoring fertility are required to improve soil structure and decrease bulk density to the point that infiltration and water-transmission capacity are significantly improved (Borst and others; 1945; Harold and others, 1962; Hendrickson and others, 1963). Such improvement is especially slow when crop demands from the soil remain heavy as they have in the Coon Creek area. This slow decrease of overland flow may allow the maintenance or even growth of drainageways and gully systems developed in the earlier regime. In severe cases, such drainage systems may take years to heal unless extensive measures are taken to speed

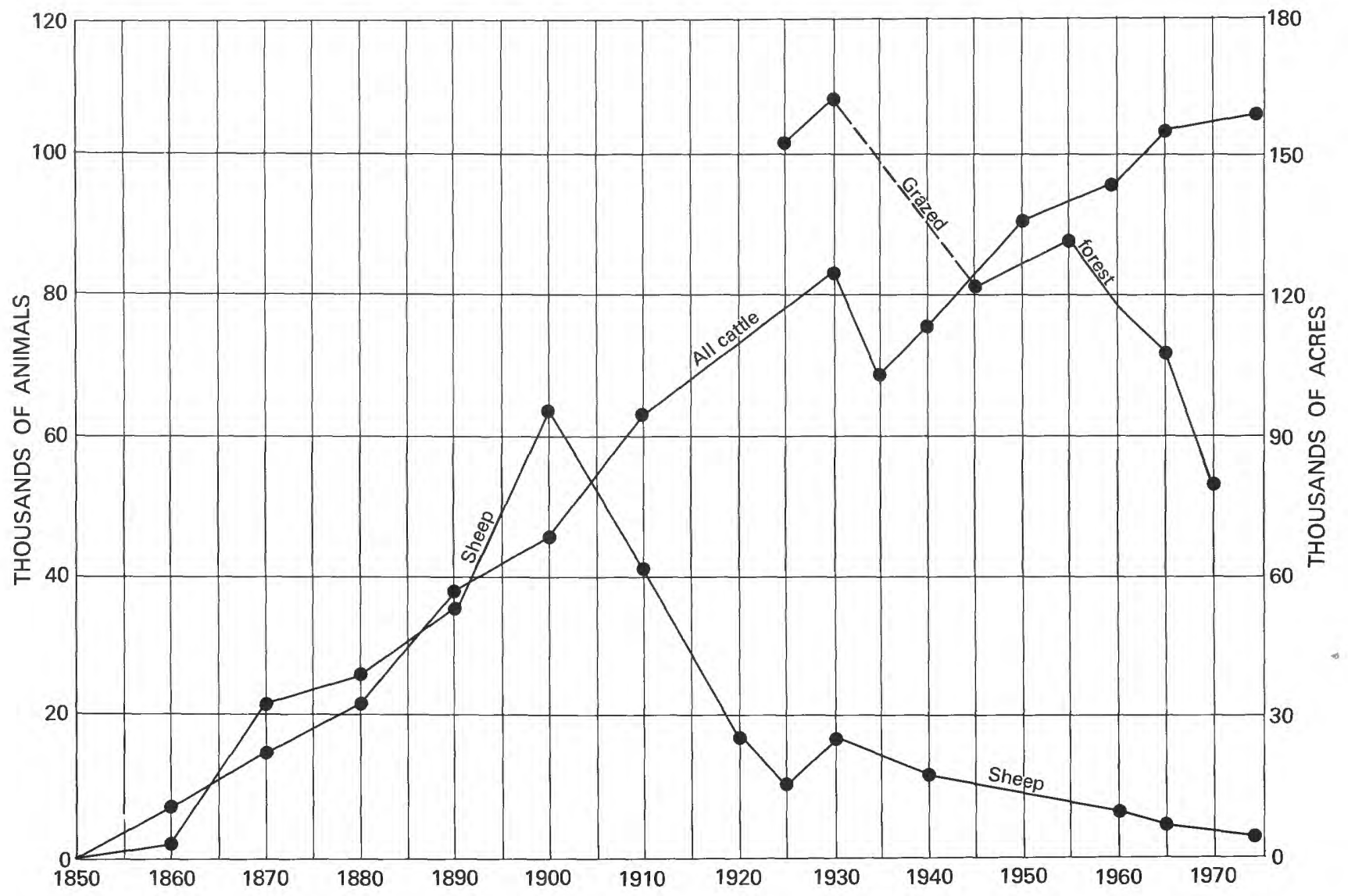

Figure 17.-Graph showing number of grazing animals, 1850-1975, and grazed forest, 1925-70, Vernon County, Wis. 
stabilization. Additionally, the cure for erosion on an upland field may not solve downstream problems, at least immediately. The purpose of some terrace systems, for example, is to efficiently route the water from the fields and into drainageways. Such systems may greatly decrease upland erosion but have much less effect on downstream storm runoff and channel erosion. A similar situation exists where soils with decreased infiltration capacities are given a thick vegetative cover which greatly limits erosion but has an initially limited effect on storm runoff. The effect in both cases is to release relatively clear storm runoff, which has the ability to erode tributary channels and to carry increased amounts of sediment downstream.

As a result, the initial decrease of erosive land use did not bring an immediate commensurate decrease of channel erosion and downstream sedimentation (see decade 1930-40, fig. 15). After a decade or so of mutually reinforcing improvements in land management, however, sedimentation rates began to decrease significantly, and this trend has continued. As fields were reshaped (fig. 3) and channel systems were removed or were healed (fig. 4), the off-field and downstream transportation of erosional debris was decreased. This change, along with the downstream results of reduced flood peaks, has decreased main valley sedimentation to a present rate considerably lower than that of upland sheet and rill erosion, a feature discussed earlier in the section on sediment delivery ratios, for the period 1962-75.

The decrease in overland flow is best shown by the healing of hillside gullies which had been active in the 1930's (fig. 16C). A quantitative approximation of the improvement is obtained by estimating the peak discharge from a 25-year, 24-hour rainfall, assuming medium antecedent moisture conditions in this case. The basin selected for analysis is watershed 33 (table 5 ), a basin of $499 \mathrm{ha}$, and the method is that of the Soil Conservation Service (1973b). Rainfall of more than $100 \mathrm{~mm}$ would, by this estimate, have produced a peak of about $39 \mathrm{~m} / \mathrm{s}$ in 1934 but should now produce $22 \mathrm{~m}^{3} / \mathrm{s}$, a 45 -percent reduction.

\section{CLIMATE AS A VARIABLE}

Climatic change, especially through changes in frequency and magnitude of precipitation, is often invoked as a hypothesis to account for geomorphic changes similar to the ones examined here (Knox and others, 1975). Has the climate changed since the 1930's? More particularly, are the decreases in erosion and sedimentation due to a decrease in rainfall or to a moderation of storm intensities? The ideal time-trend analysis of the precipitation as it relates to erosion would be the
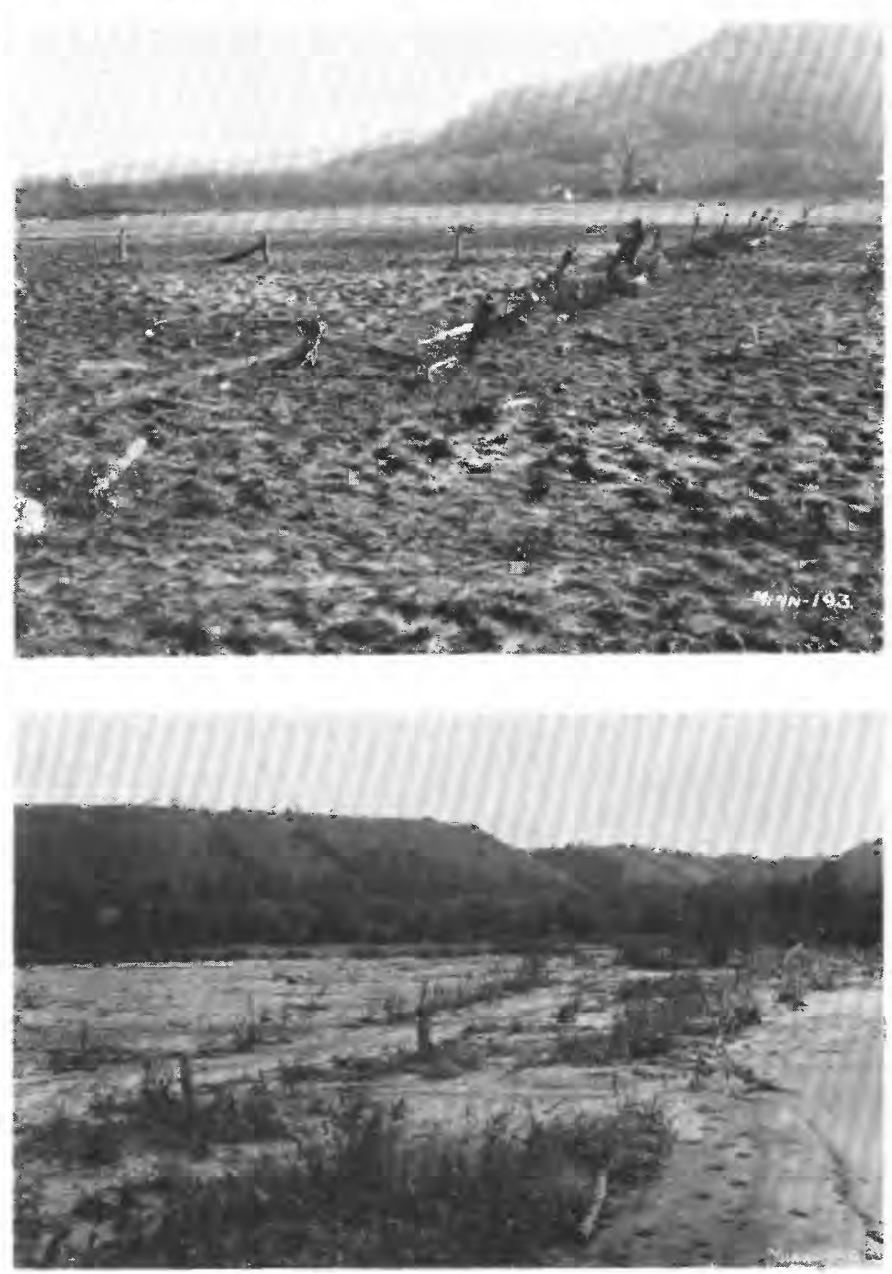

FIGURE 18.-Photographs showing deterioration of flood-plain fields and pasture from accelerated sedimentation during the period 1936-38. This damage increased the pressure on upland areas. Photographs by USDA Soil Conservation Service.

computation of erosive index (EI) values for succeeding years (Wischmeier and Smith, 1965). However, EI computations require the maximum 30 -minute intensity and the total rainfall of each storm, while Weather Bureau records give only daily amounts up to 1962 , with hourly amounts for some stations thereafter.

\section{THE COON CREEK AREA, 1927-73}

We first analyzed precipitation in the area surrounding Coon Creek for the period 1927-73 (fig. 19). Two stations were in operation in 1927 (the closest being at La Crosse, Wis.), but the number had increased to 4 by 1932 and to 10 by 1944 .

Our approach was to first analyze time trends of total annual precipitation. Figure $19 \mathrm{~A}$ shows the deviation (in number of standard deviations) of each year's total rainfall from the 1927-73 mean of all stations. No overall time trend is discernible. However, 

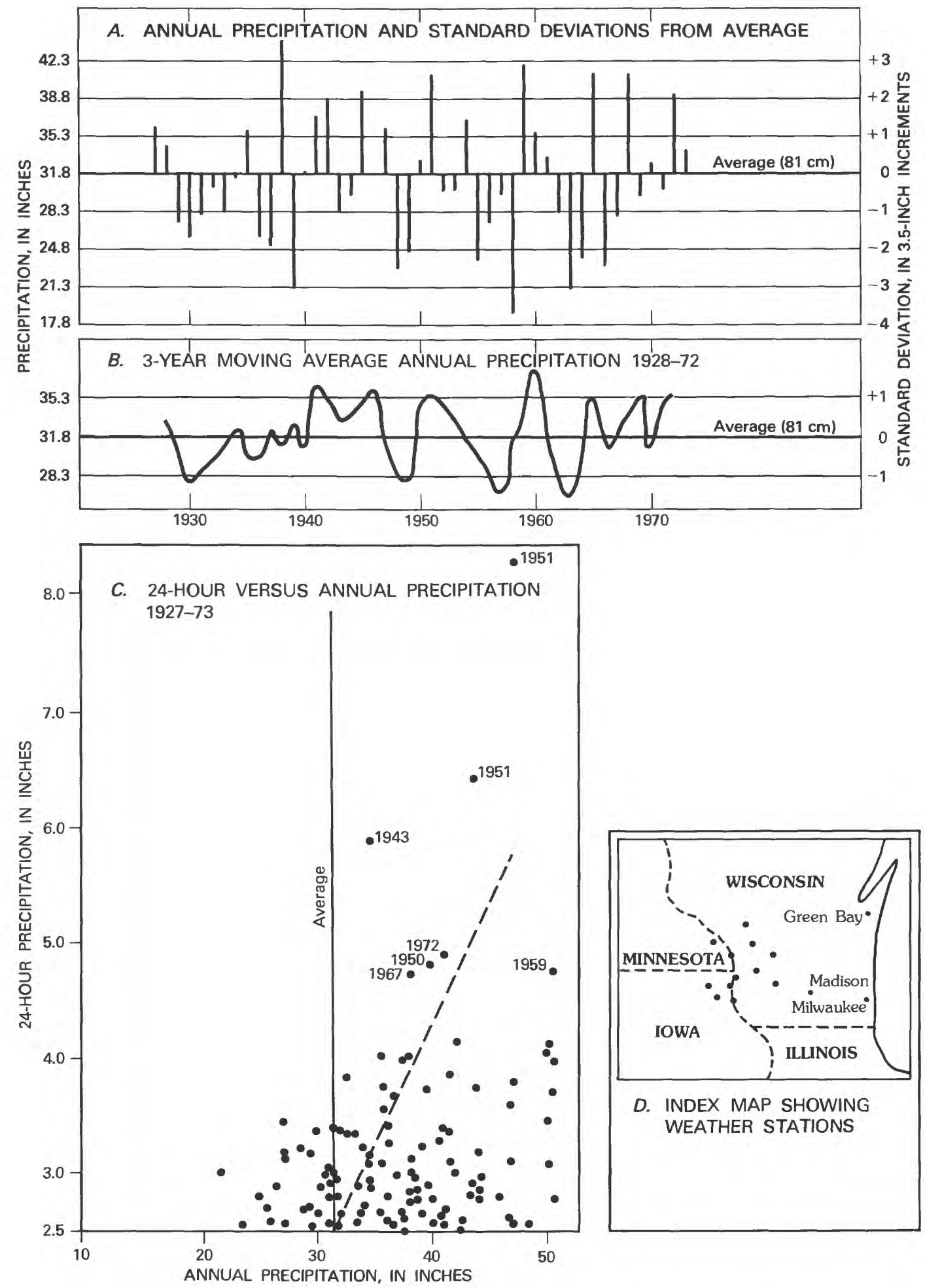

FIGURE 19.-Graphs showing precipitation trends in the Coon Creek area, 1927-73.

only 2 years between 1929 and 1940 inclusive were appreciably wet ( 0.5 standard deviation above the mean). For the period 1962-73 inclusive, 4 years were appreciably above the mean.
We then attempted to damp the annual oscillation by computing a 3-year moving average (fig. 19B). This indicated 3- to 7-year cycles, but no overall pattern. The first half of the 1930's was rather dry, and the sec- 
ond half was only slightly drier than normal. The first half of the 1960's was very dry; the second half and the early 1970's were wet.

Annual precipitation figures do not in themselves tell much about runoff and erosive effects. For example, did 32 inches of precipitation come in many moderate showers, or did most of the annual amount come in a few intense storms of several inches each? To examine this question we plotted intense 24-hour storms against the annual precipitation for the year of the storm (fig. 19C). For the purpose of this discussion, a large storm is taken as one of 2.5 inches of rainfall or more, 2.5 inches being the 24-hour rainfall magnitude of 1-year frequency. Figure $19 \mathrm{C}$ suggests an association between wet years and intense storms. No year of less than mean precipitation has a storm greater than 3.5 inches in 24 hours, whereas wet years had storms as great as 8 inches. Expressed another way, only about 20 percent of all large storms occurred in dry years, and these storms were among the smaller of the large storms. We may say that the more intense storms are associated with the wetter years indicated in figures $19 A$ and $19 B$. The data suggest that the rainfall of the 1930's was no more erosive than that of the 1960 's and early 1970's and may well have been somewhat less. Thus, we cannot attribute the decrease of erosion and sedimentation to amelioration of climatic conditions.

\section{THE ENTIRE DRIFTLESS AREA, 1867-1974}

In our earlier discussion we presented evidence that erosion and sedimentation increased by approximately three orders of magnitude within $75-80$ years after European settlement. We then presented further evidence that erosion and sedimentation have been drastically reduced, perhaps by as much as two orders of magnitude, within the past 40 years. Based on our observations and studies over much of the Driftless Area and drawing from the available literature (Adams, 1940, 1942; Happ, 1944; Knox, 1977; Kunsman, 1944), we think it likely that much of the Driftless Area has undergone a history similar to that of the Coon Creek basin. It is important to know if climatic change has played a role in these remarkably rapid landscape changes. Thus, we attempt to analyze rainfall variation, as it affects soil erosion, for the entire Driftless Area during the period 1867-1974. We proceed as before, but time and space are greatly expanded. Only 2 stations were available in 1867, but this number had increased to 22 by 1895 and to 43 by 1954 . We presume the weather stations give a representative sample, but the limited number in the earlier period make that assumption uncertain. However, we can be more definite about the period since 1900 .
The time-trend of average annual precipitation is shown in figure $20 \mathrm{~A}$. The overall trend is a decrease of annual precipitation, but that is greatly influenced by the wet years of the early period. Of greater import to this study is the concave-upward nature of the trend with wetter years early and late during the period and drier years during the middle of the period. This is conveniently demonstrated by arbitrarily dividing the record into two periods. For 1867-1920, the trend is negative, whereas for 1920-74, the trend is positive. As before, larger storms were associated with wetter years (fig. 20B). This concave-upward trend (fig. 20A) approximates the annual flood series for the region recorded on the Mississippi River at Keokuk, Iowa (Knox and others, 1975, front cover). Flood flows there were higher up to about 1895 and after 1960, and lower during the intervening period. Thus, from a climatic standpoint alone, one would expect greater potential for soil erosion during the early and late periods. Such a trend, however, is negatively correlated with our findings (figs. 10, 11, 12,13, and 14); that is, the wetter years, with greater storms and higher runoff, were coincident with the clear streams of the presettlement and early settlement period and with the present (1962-75), while the drier years tend to coincide with the intervening period of extreme erosion and sedimentation demonstrated in this study.

A 3-year moving average (fig. 20D) indicates that the wet years of the early period were followed by a deep and prolonged dry period in the 1880's. Since that time there have been lesser wet and dry cycles of 3-7 years, but none of these cycles can be related to any major erosional cycle that we have identified.

Perhaps the best analysis of precipitation change in the Driftless Area is a chronological array (fig. 21). Stations were selected on the basis of continuous operation and complete published data. The period begins with 1931 because by that time the optimum number of stations had become available. Major features of the array are (1) few intense rainstorms during the 1930's and (2) periods of many large rainstorms in the early 1940 's, early 1950's, and early 1960's. The late 1960's and early 1970's were wet, but large storms were not concentrated as they were in the three earlier periods. There is no correlation of this chronological pattern with that of erosion or sedimentation (fig. 14).

Finally, the consistency of our data argues against a significant cyclic climatic variable. For example, the rates of sedimentation at different sites are remarkably similar (figs. 11 and 13). Given the spread of dates at the six sites, one should expect at least one out-ofphase, or even bimodal, curve in the group if precipitation trends had exerted a significant effect. Although we acknowledge that the 5- and 10-year precipitation 


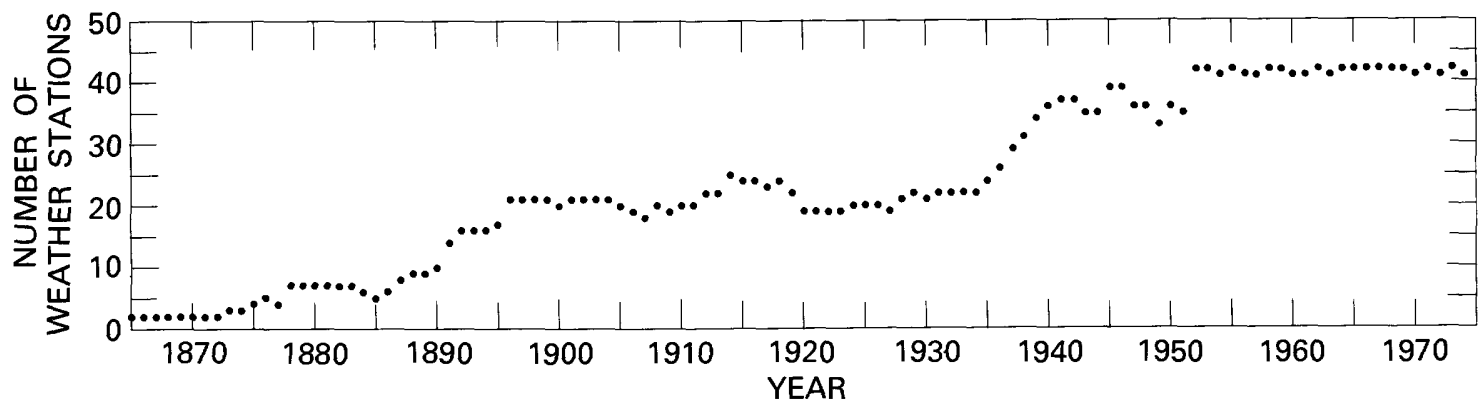

A. Number of weather stations

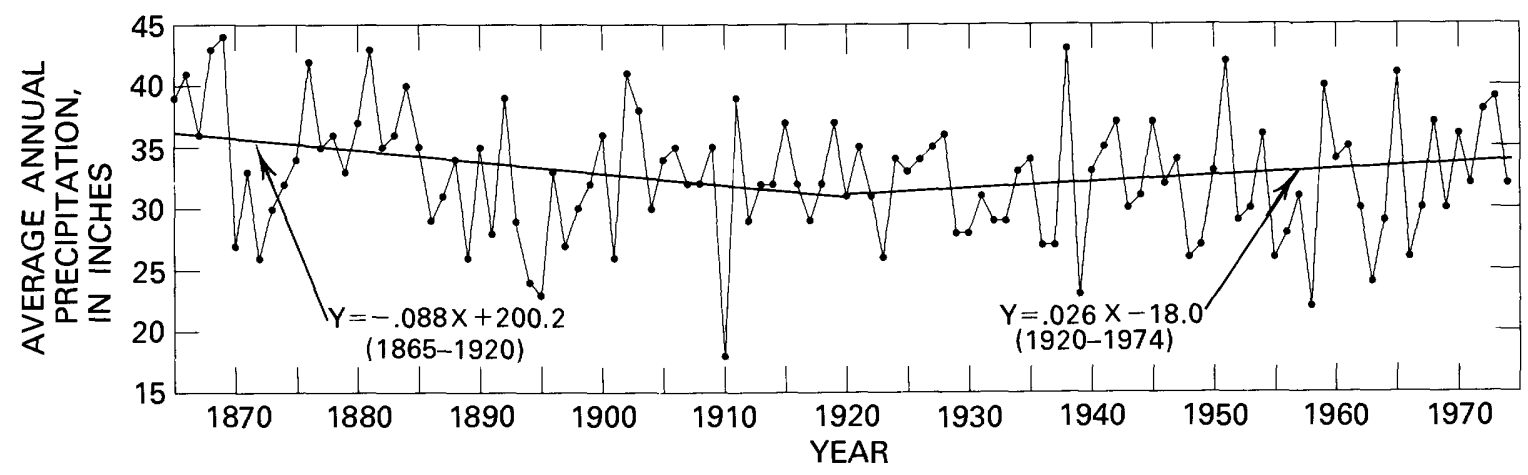

$B$. Average annual precipitation and time trends

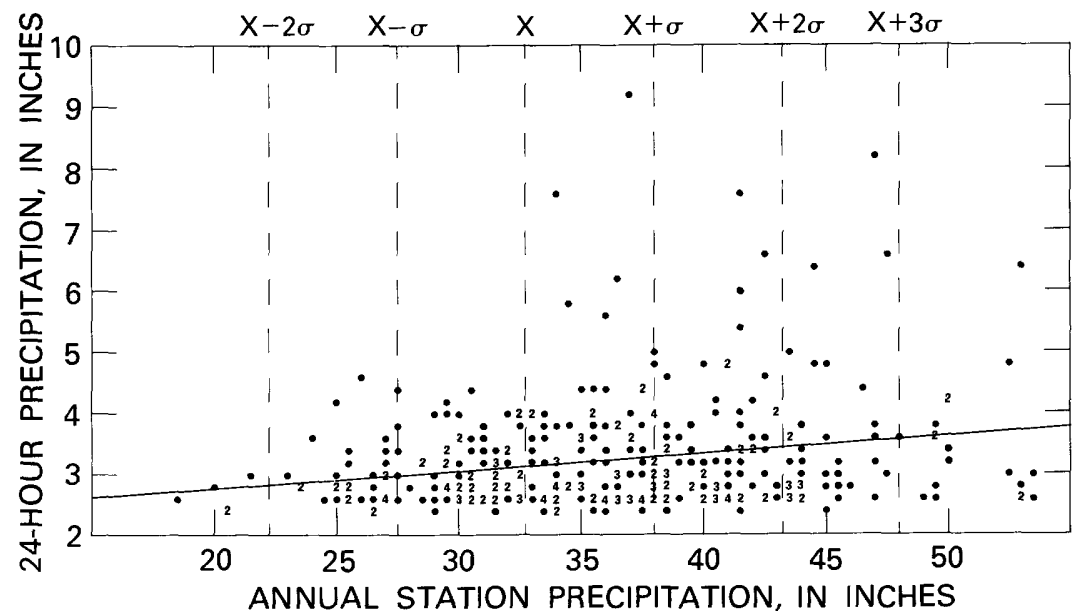

C. Relation of annual station precipitation and storms exceeding 2.5 inches $(10 \mathrm{~cm})$ in 24 hours

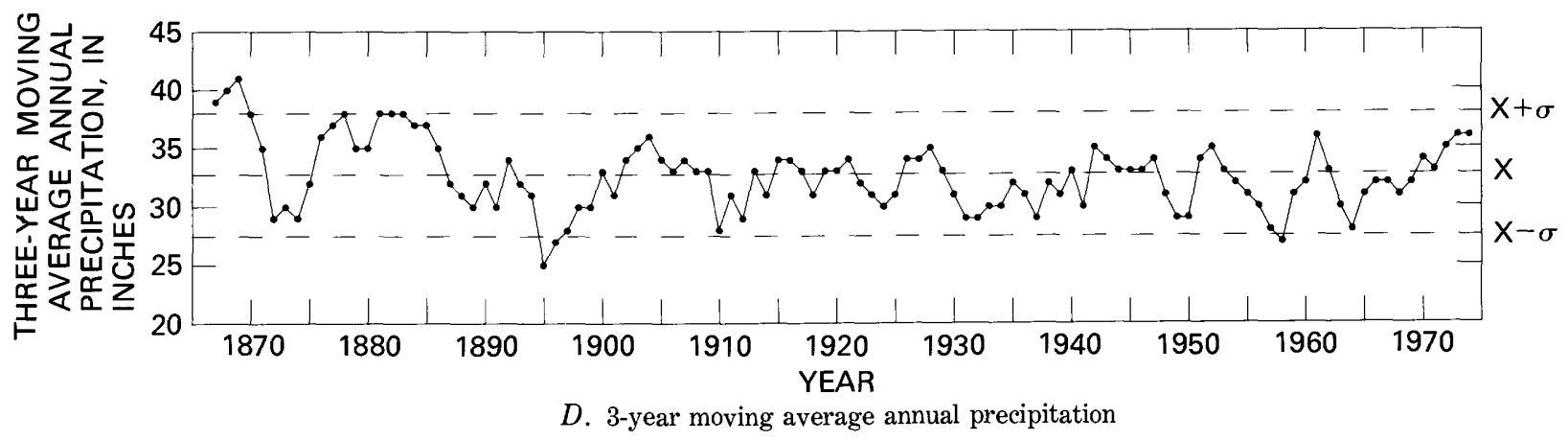

FIGURE 20.-Graphs showing precipitation trends in the Driftless Area, 1867-1974. 


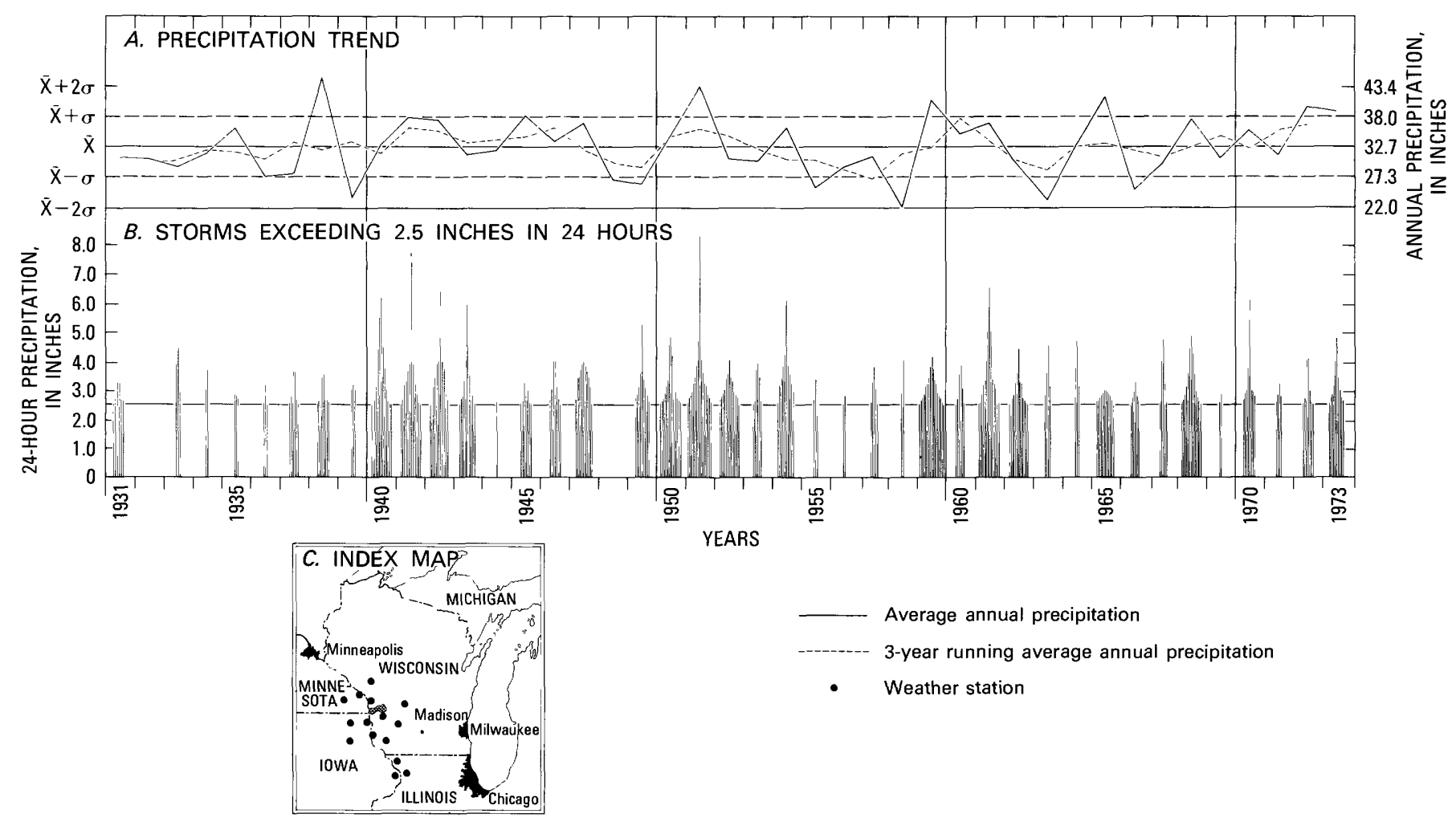

Figure 21.-Graphs showing precipitation trends at 15 selected stations in the Driftless Area, 1931-73.

cycles would have some effect on erosion and sedimentation rates in a basin that had already been disturbed, the traces of this effect were subsumed in the general trend which is best correlated with erosive land use (figs. 14 and 15).

Overall, we see no relation of rates of erosion and sedimentation to precipitation. We believe that the role of climatic cycles has been to superimpose perturbations on the overall trends caused by land use and land management.

figure 5. The three-county area has more nonagricultural land than does the Coon Creek basin (as characterized by the 10 sample basins examined in this study) and thus has a smaller percentage of the area in cropland and a larger percentage in forest. However, the changes in land use since 1934 have been proportionally similar between the three-county area and the Coon Creek basin. For example, cropland decreased by

\section{IS COON CREEK REPRESENTATIVE?}

Given that significant reduction of erosion and sedimentation have occurred in the Coon Creek basin, is our sample representative of the surrounding area in the Driftless Area? We shall look at both land use and conservation practices.

The changes in land use for the three-county area surrounding the Coon Creek basin area are shown in
6 percent in the larger area over the period 1934-67 and by 6 percent in the Coon Creek basin. At the same time the increases in pasture were 8 percent and 13 percent for the two areas, respectively, while forest increased 9 percent in the large area and 10 percent in the Coon Creek basin. Thus, the trend in both areas since 1934 has been a comparable slight increase in forest and pasture at the expense of cropland.

\section{CONSERVATION PRACTICES}

The Coon Creek basin was established as a soil conservation demonstration area in the 1930's to set an example from which, it was hoped, proper conservation practices would diffuse into the surrounding area. That this succeeded can now be seen on the landscape, whether from an aircraft or auto or on aerial photographs: contouring and contour-strip farming are widespread phenomena on the Driftless Area landscape.

The diffusion of contour-strip farming southward into neighboring counties will serve as an example (fig. 22). In 1939, most of the farms that had adopted contour-strip farming were in or very near the Coon Creek watershed. By 1949 the practice had spread greatly, but the major concentration was still near the area initially treated. By 1955, the number of adopters was still increasing and the distribution was becoming 


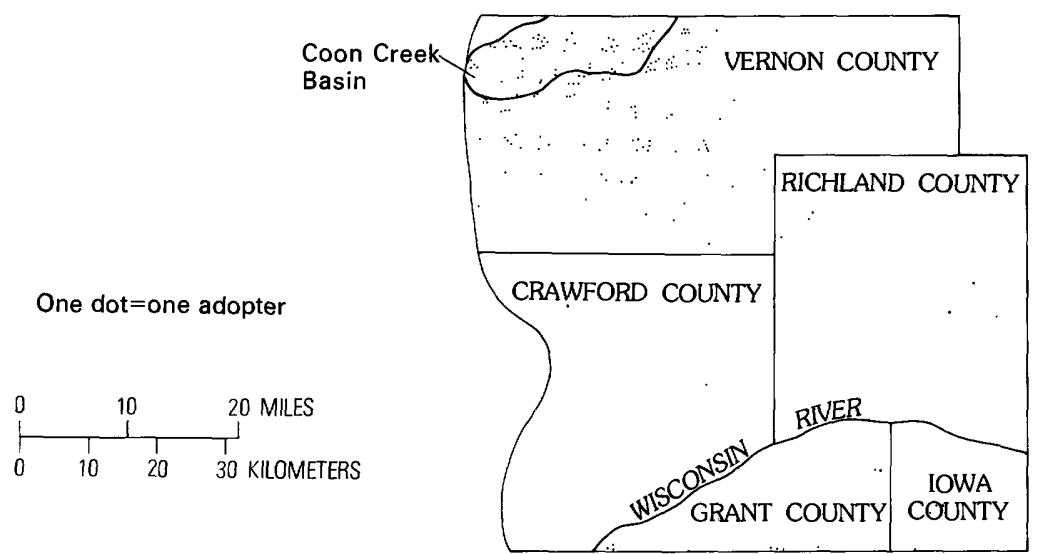

1939 (233 ADOPTERS)
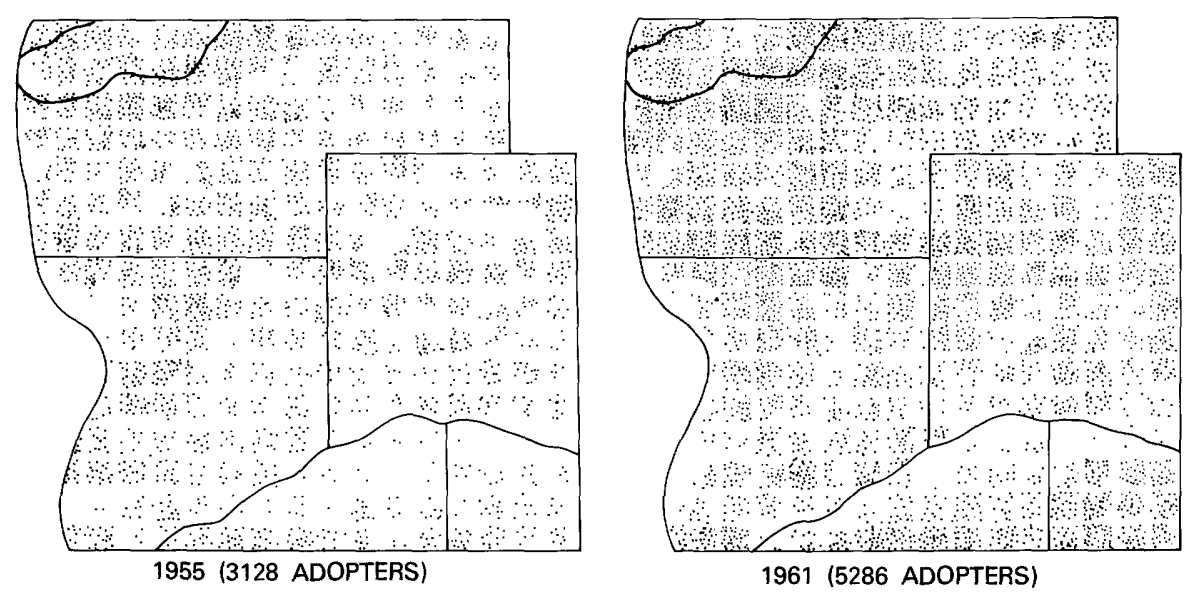

1961 (5286 ADOPTERS)

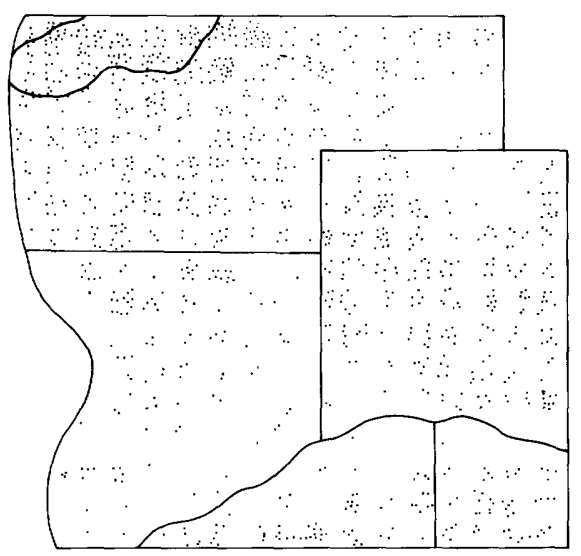

1949 (1304 ADOPTERS)

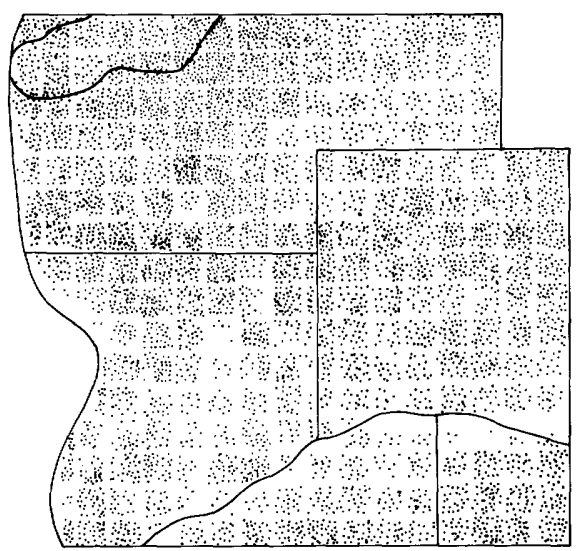

1967 (6402 ADOPTERS)

Figure 22.-Spread of contour-strip farming from the Coon Creek Conservation Demonstration Area, Wisconsin, $1939-67$. One dot = one adopter. Source: H. E. Johansen, 1969.

more equalized. By 1967, the number of adopters had more than doubled since 1955 and no concentration was evident. The areas of lower density are on flatter areas and in the Wisconsin River valley where conservation measures against erosion are less necessary than they are in the steeper parts of the area. Based on these data, it appears that the practice of contour-strip cropping had become widespread across this portion of the Driftless Area by 1967. If other land-management practices have increased everywhere in proportion to increases in contour stripcropping (a reasonable assumption based on our observations), then there should be little difference in total land management. Indeed, 7 years of observation across the Driftless Area strongly indicate to us that the changes in land use and erosion found in the Coon Creek basin are typical of the region.

\section{CONCLUSIONS}

We conclude that erosion and sedimentation have been dramatically reduced in the Coon Creek basin and in most of the Driftless Area. These reductions have been caused principally by improvements in land management and, to a lesser degree, by changes in land use. Climatic changes may have imposed minor perturbations on the observed trends in erosion and sedimentation, but they do not seem to have been an important causal factor.

In the decade or more since 1965 when Held and Clawson made their lament, the fervor of the environmental crusade has often overshadowed the considerable conservation accomplishments of the past. Indeed, we have often been given to understand that environmental degradation is a recent phenomenon. This study of the Coon Creek basin shows that constructive efforts have been made to overcome such degradation and that these efforts have been largely successful in this case.

\section{REFERENCES}

Adams, Clifford, 1940, Modern sedimentation in the Galena River Valley, Illinois and Wisconsin: Iowa City, University of Iowa, unpublished M.S. thesis, $72 \mathrm{p}$.

_- 1942, Accelerated sedimentation in the Galena River Valley, Illinois and Wisconsin: Iowa City, University of Iowa, unpublished Ph.D. dissertation, $67 \mathrm{p}$. 
Borst, H. L., McCall, A. G., and Bell, F. G., 1945, Investigations in erosion control and the reclamation of eroded land at the Northwest Appalachian Conservation Experiment Station, Zanesville, Ohio, 1934-42: U.S. Department of Agriculture Technical Bulletin 888, $95 \mathrm{p}$.

Brown, M. H., and Nygard, I. J., 1941, Erosion and related land use conditions in Winona County, Minnesota: U.S. Department of Agriculture, Soil Conservation Service Erosion Survey 17, 33 p.

Brune, G. M., 1953, Trap efficiency of reservoirs: American Geophysical Union Transactions, v. 34, p. 407-418.

Butzer, K. W., 1975, Soil erosion: a problem in man-land relationships, in Manners, I. and Mikesell, M., eds. Perspectives on Environment: Washington, D.C., Association of American Geographers, p. 57-78.

Happ, S. C., 1944, Effect of sedimentation on floods in the Kickapoo Valley, Wisconsin: Journal of Geology, v. 52, p. 53-68.

Happ, S. C., Rittenhouse, G., and Dobson, G. C., 1940, Some principles of accelerated stream and valley sedimentation: U.S. Department of Agriculture Technical Bulletin 695, $133 \mathrm{p}$.

Harold, L. L., Brakensiek, D. L., McGuinness, J. L., Amerman, C. R., and Dreibelbis, F. R., 1962, Influence of land use and treatment on the hydrology of small watersheds at Coshocton, Ohio, 19381957: U.S. Department of Agriculture Technical Bulletin 1256, $194 \mathrm{p}$.

Hays, O. E., McCall, A. G., and Bell, F. G., 1949, Investigations in erosion control and the reclamation of eroded land at the Upper Mississippi Valley Conservation Experiment Station near LaCrosse, Wisconsin, 1933-43: U.S. Department of Agriculture Technical Bulletin 973, 87 p.

Held, R. B., and Clawson, Marion, 1965, Soil conservation in perspective: Baltimore, Johns Hopkins Press, 344 p.

Hendrickson, B. D., Barnett, A. P., Carreker, J. R., and Adams, W. E., 1963, Runoff and erosion control studies on Cecil soils on the southern piedmont: U.S. Department of Agriculture Technical Bulletin 1281, $33 \mathrm{p}$.

Johansen, H. E., 1969, Spatial diffusion of contour strip cropping in Wisconsin: Madison, University of Wisconsin, unpublished M.S. thesis, $66 \mathrm{p}$.

Johnson, W. C., 1976, The impact of environmental change of fluvial systems: Kickapoo River, Wisconsin: Madison, University of Wisconsin, unpublished Ph.D. dissertation, $294 \mathrm{p}$.

Keyes, D. M., and Anderson, H. O., 1939, Description of the Coon Valley Soil Conservation Demonstration Area: Unpublished study on file at office of State Conservationist, Soil Conservation Service, Madison, Wis., 38 p.

Knox, J. C., 1977, Human impacts on Wisconsin stream channels: Annals, Association of American Geographers, v. 67, p. 323-342.

Knox, J. C., Bartlein, P. J., Hirschboek, K. K., and Muckenhirn, R. J., 1975 , The response of floods and sediment fields to climatic variation and land use in the Upper Mississippi Valley: University of Wisconsin-Madison, Institute for Environmental Studies Report $52,76 \mathrm{p}$

Kunsman, H. S., 1944, Stream and valley sedimentation in Beaver Creek Valley, Wisconsin: Madison, University of Wisconsin, un published Ph.D. thesis, 134 p.

Lund, S. W., 1976, Conservation and soil lost through fluvial proc esses, Coon Creek Watershed, Wisconsin, 1934 to 1975 Milwaukee, University of Wisconsin, unpublished M.S. thesis.

McKelvey, V. E., 1939, Stream and valley sedimentation in the Coon Creek Drainage Basin, Wisconsin: Madison, University of Wisconsin, unpublished M.A. thesis, 122 p.

Owen, D. D., 1847, Report of geological reconnaissance of the Chippewa Land District of Wisconsin: U.S. 30th Congress, 1st. session, U.S. Senate Executive Document 57, 134 p.
1852, Report of a geological survey of Wisconsin, Iowa and Minnesota: Philadelphia, Lippincott, Grambo and Co., 63 p.

Sartz, R. S., 1976, Sediment yield from steep lands in the Driftless area, in Proceedings of the Third Federal Inter-Agency Sedimentation Conference, Denver, Water Resources Council, Section 1: p. $123-131$.

Soil Conservation Service, U.S. Department of Agriculture, undated, Farming against erosion: the experiences and recommendations resulting from five years of efforts to check erosion in the Coon Creek area at Coon Valley, Wisconsin: Madison, Soil Conservation Office, unpublished manuscript, $107 \mathrm{p}$.

- 1942, Hydrologic studies at the Coon Creek Demonstration Project, Soil Conservation Service-Wisconsin-1, Coon Valley, Wisconsin: Technical Pamphlet 46, 4 p., appendices.

- - 1960-1963, As built plans (design data of Coon Creek flood retention structures): on file at Soil Conservation Service district field offices, Sparta and Viroqua, Wisconsin.

1971, Sedimentation: National Engineering Handbook, Section 3: Washington, D.C., U.S. Government Printing Office.

- 1973a, Estimating soil loss resulting from water and wind erosion in the Midwest: Lincoln, Nebraska.

- - 1973b, A method for estimating volume and rate of runoff in small watersheds: Technical Publication 149, 19 p., appendix.

- 1975 , Procedure for computing sheet and rill erosion in project areas: Soil Conservation Service Technical Release 51, 16 p.

- - 1976, Wisconsin technical guide notice: CONS-WI-16: Madison, Wisconsin.

Trimble, S. W., 1974, Man-induced soil erosion on the Southern Piedmont, 1700-1970: Ankeny, Iowa, Soil Conservation Society of America, $180 \mathrm{p}$.

-— 1975, Denudation studies: can we assume stream steady state?: Science, v. 188 , p. 1207-1208.

- - 1976a, Sedimentation in Coon Creek Valley, Wisconsin, in Proceedings of the Third Federal Inter-Agency Sedimentation Conference, Denver, Water Resources Council, section 5, p. 100-112.

1976b, Unsteady state denudation: Science, v. 191, p. 871.

- 1976c, Sedimentation rates in Coon Creek Valley, Wisconsin: oral presentation at the Inter-Agency Sedimentation Conference, Denver, Colorado, March 1976.

- 1977, The fallacy of stream equilibrium in contemporary denudation studies: American Journal of Science, v. 277, p. 876-887.

- - in press, Changes in sediment storage in the Coon Creek basin Driftless Area, Wisconsin, 1853-1975: p. 13, 17, 46.

Trowbridge, A. L., undated, Conservation survey report of Coon Creek Watershed, Coon Valley, Wisconsin: Section of Conservation Surveys, Soil Conservation Service, unpublished study on file at office of State Conservationist, Soil Conservation Service, Madison, Wisconsin, $95 \mathrm{p}$.

U.S. Army Corps of Engineers, 1867, Annual Report: Washington, U.S. Government Printing Office.

U.S. House of Representatives, 1867, Survey of Upper Mississippi River: Executive Document 58, 39th Congress, 2nd Session, 116 p.

Ward, R. C., 1975, Principles of Hydrology, 2nd ed.: Maidenhead, McGraw-Hill, 367 p.

Wischmeier, W. H., and Smith, D. D., 1965, Predicting rainfall erosion losses from cropland east of the Rocky Mountains: U.S. Department of Agriculture, Agriculture Research Service Agriculture Handbook 282, Washington.

Wisconsin State Department of Agriculture, undated, Wisconsin Land Inventory: Land Economic Inventory and Land Use Section, Madison, Wisconsin. 

APPENDICES

APPENDIX I.-Cropping plan for the Stromstad Farm, 1939-44. (Refer to figs. 2, 3, and 4)

[Data from Soil Conservation Service, Madison, Wisc. Alf and Tim, alfalfa and timothy; Cl and Tim, clover and timothy]

\begin{tabular}{|c|c|c|c|c|c|c|c|}
\hline Field & Acres & 1939 & 1940 & 1941 & 1942 & 1943 & 1944 \\
\hline 1 & 41.5 & \multicolumn{6}{|c|}{ Ungrazed Woodland } \\
\hline 2 & 1.3 & \multicolumn{6}{|c|}{ 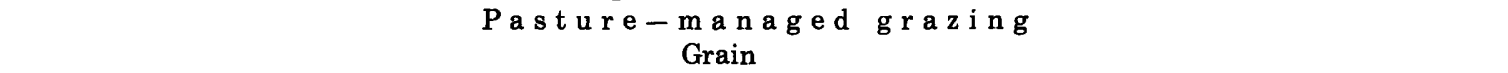 } \\
\hline $3 \mathbf{a}$ & 2.8 & Corn & $\begin{array}{l}\text { Corn } \\
\text { Grain }\end{array}$ & (Alf and Tim) & Alf and Tim & $\begin{array}{l}\text { Alf and Tim } \\
\text { Grain }\end{array}$ & Alf and Tim \\
\hline $3 b$ & 2.7 & Alfalfa and Bluegrass & $\begin{array}{l}\text { (Cl and Tim) } \\
\text { Grain }\end{array}$ & Corn & $\mathrm{Cl}$ and Tim & (Alf and Tim) & Alf and Tim \\
\hline $3 c$ & 2.5 & Corn & (Alf and Tim) & Alf and Tim & $\begin{array}{l}\text { Alf and Tim } \\
\text { Grain }\end{array}$ & Alf and Tim & Corn \\
\hline $3 d$ & 1.9 & (Cl and Tim) & Timothy & Corn & (Alf and Tim) & Alf and Tim & Alf and Tim \\
\hline $3 e$ & 2.8 & $\mathrm{Cl}$ and Tim & $\begin{array}{l}\text { Corn } \\
\text { Grain }\end{array}$ & $\begin{array}{c}\text { Grain } \\
(\mathrm{Cl} \text { and } \mathrm{Tim})\end{array}$ & $\mathrm{Cl}$ and $\mathrm{Tim}$ & Corn & $\begin{array}{c}\text { Grain } \\
\text { (Alf and Tim) }\end{array}$ \\
\hline $4 a$ & 1.1 & Tobacco & $\begin{array}{l}\text { (Cl and Tim) } \\
\text { Grain }\end{array}$ & $\mathrm{Cl}$ and Tim & Corn & Tobacco & $\begin{array}{l}\text { Tobacco } \\
\text { Grain }\end{array}$ \\
\hline $4 b$ & 1.3 & Corn & (Cl and Tim) & $\mathrm{Cl}$ and Tim & $\begin{array}{l}\text { Tobbaco } \\
\text { Grain }\end{array}$ & Tobacco & (Alf and Tim) \\
\hline $4 \mathrm{c}$ & 1.2 & Tobacco & Tobacco & Tobacco & (Alf and Tim) & Alf and Tim & Alf and Tim \\
\hline $\begin{array}{l}5 \\
6\end{array}$ & $\begin{array}{l}0.8 \\
2.0\end{array}$ & \multicolumn{4}{|c|}{$\begin{array}{r}\text { Terrace Outlet-Pasture-Regulated } \\
\text { Pasture-managed grazing }\end{array}$} & Grazing & \\
\hline $7 a$ & 1.8 & Corn & $\begin{array}{c}\text { Grain } \\
\text { (Alf and Tim) }\end{array}$ & Alf and Tim & $\begin{array}{l}\text { Alf and Tim } \\
\text { Grain }\end{array}$ & Alf and Tim & Corn \\
\hline $7 \mathrm{~b}$ & 1.9 & $\begin{array}{l}\text { Alfalfa and Bluegrass } \\
\text { Grain }\end{array}$ & Emerging Hay & Corn & (Alf and Tim) & Alf and Tim & $\begin{array}{l}\text { Alf and Tim } \\
\text { Grain }\end{array}$ \\
\hline $7 \mathrm{c}$ & 2.1 & (Alf and Tim) & Alf and Tim & $\begin{array}{l}\text { Alf and Tim } \\
\text { Grain }\end{array}$ & Alf and Tim & Corn & (Alf and Tim) \\
\hline $7 d$ & 2.1 & Alfalfa and Bluegrass & $\begin{array}{l}\text { Corn } \\
\text { Grain }\end{array}$ & (Alf and Tim) & Alf and Tim & $\begin{array}{l}\text { Alf and Tim } \\
\text { Grain }\end{array}$ & Alf and Tim \\
\hline $7 \mathrm{e}$ & 1.8 & Corn & (Cl and Tim) & $\begin{array}{l}\mathrm{Cl} \text { and Tim } \\
\text { Grain }\end{array}$ & Corn & (Alf and Tim) & Alf and Tim \\
\hline $7 f$ & 1.8 & Alfalfa and Bluegrass & Corn & (Alf and Tim) & Alf and Tim & Alf and Tim & Corn \\
\hline $7 \mathrm{~g}$ & 1.9 & $\begin{array}{l}\text { 1.0 Alf and Tim } \\
0.9 \text { Grain (Alf and Tim) } \\
\text { Grain }\end{array}$ & Alf and Tim & Corn & $\begin{array}{c}\text { Grain } \\
\text { (Alf and Tim) }\end{array}$ & Alf and Tim & $\begin{array}{l}\text { Alf and Tim } \\
\text { Grain }\end{array}$ \\
\hline $8 a$ & 0.9 & (Alf and Tim) & Alf and Tim & Alf and Tim & Alf and Tim & $\begin{array}{l}\text { Corn } \\
\text { Grain }\end{array}$ & (Alf and Tim) \\
\hline $8 b$ & 1.0 & $\begin{array}{l}\mathrm{Cl} \text { and Tim } \\
\text { Grain }\end{array}$ & Tobacco & $\begin{array}{c}\text { Tobacco } \\
\mathrm{Cl} \text { and Tim }\end{array}$ & Tobacco & (Alf and Tim) & Alf and Tim \\
\hline $8 \mathrm{c}$ & 0.8 & $\begin{array}{l}\text { (Cl and Tim) } \\
\text { Grain }\end{array}$ & $\mathrm{Cl}$ and Tim & (Reseed) & $\begin{array}{l}\mathrm{Cl} \text { and Tim } \\
\text { Grain }\end{array}$ & Corn & Tobacco \\
\hline $9 a$ & 1.1 & (Cl and Tim) & $\begin{array}{l}\mathrm{Cl} \text { and Tim } \\
\text { Grain }\end{array}$ & Corn & (Cl and Tim) & $\begin{array}{l}\mathrm{Cl} \text { and } \mathrm{Tim} \\
\text { Grain }\end{array}$ & Corn \\
\hline $9 b$ & 4.0 & Corn & (Cl and Tim) & $\mathrm{Cl}$ and Tim & Corn & (Alf and Tim) & Alf and Tim \\
\hline $9 c$ & 2.8 & $\begin{array}{c}\text { Grain } \\
(\mathrm{Sw} . \mathrm{Cl}) \\
\mathrm{Cl} \text { and Alf }\end{array}$ & Corn & $\begin{array}{c}\text { Grain } \\
\text { (Alf and Tim) }\end{array}$ & Alf and Tim & Alf and Tim & $\begin{array}{l}\text { Alf and Tim } \\
\text { Grain }\end{array}$ \\
\hline $9 d$ & 2.8 & Tim & Alf and Tim & Alf and Tim & $\begin{array}{l}\text { Alf and Tim } \\
\text { Grain }\end{array}$ & Corn & (Alf and Tim) \\
\hline $9 e$ & 2.0 & Alfalfa and Bluegrass & $\begin{array}{c}\text { Emerging Hay } \\
\text { Grain }\end{array}$ & Corn & (Alf and Tim) & Alf and Tim & Alf and Tim \\
\hline $9 f$ & 2.0 & Corn & (Alf and Tim) & Alf and Tim & Alf and Tim & Alf and Tim & Corn \\
\hline 10 & 6.5 & & Past & $\begin{array}{l}- \text { ma n a } \\
5-0 \text { p } n\end{array}$ & $\begin{array}{l}\text { grazing } \\
\text { ture }\end{array}$ & & \\
\hline
\end{tabular}




\section{APPENDIX I-(Continued)}

APPENDIX I.-Cropping plan for the Stromstad Farm, 1939-44. (Refer to figs. 2, 3, and 4)

[Data from Soil Conservation Service, Madison, Wisc. Alf and Tim, alfalfa and timothy; Cl and Tim, clover and timothy]

\begin{tabular}{|c|c|c|c|c|c|c|c|}
\hline Field & Acres & 1939 & 1940 & 1941 & 1942 & 1943 & 1944 \\
\hline 11 & 18.5 & & $4.5-W \circ o d$ & pasture ma & naged gra & $\mathrm{ng}$ & \\
\hline 12 & 2.4 & \multirow{3}{*}{\multicolumn{6}{|c|}{$\begin{array}{c}\text { Ungrazed woodland } \\
\text { Ungrazed woodland } \\
3.1-\text { open pasture } \\
3.9-\text { Wooded pasture managed grazing }\end{array}$}} \\
\hline 13 & 3.2 & & & & & & \\
\hline 14 & 7.0 & & & & & & \\
\hline 15 & 1.0 & (Cl and Tim) & $\mathrm{Cl}$ and $\mathrm{Tim}$ & Corn & (Alf and Tim) & Alf and Tim & Alf and Tim \\
\hline 16 & 1.8 & & & $\begin{array}{l}\mathrm{H} \text { a y } \mathrm{l} \text { a n } \mathrm{d} \\
\text { Grain }\end{array}$ & & & \\
\hline 17 & 0.4 & Potatoes & Corn & (Alf and Tim) & Alf and Tim & Alf and Tim & Alf and Tim \\
\hline Total & $\begin{array}{r}4.5 \\
138.0\end{array}$ & $\begin{array}{l}\text { Farmstead } \\
\text { acres }\end{array}$ & & & & & \\
\hline
\end{tabular}

APPENDIX II.-Assumptions made concerning land management and "C" factors (from Lund, 1976, appendix II). "C" factors interpolated from Soil Conservation Service, 1976

I. 1934

A. Medium stocked stand, unmanaged (grazed and burned), 40 to 70 percent tree canopy, 70 percent ground cover, $C=0.30$.

B. Pasture Overgrazed bluegrass, no appreciable canopy, 60 percent ground cover, $C=0.04$.

C. Farmyard

Grass, no appreciable canopy, 50 percent ground cover, $C=$ 0.07 .

D. Cropland

Uniform 3-year rotation of 1 year row crop, 1 year small grain, and 1 year hay-meadow (ROM), fall plowed, conventional tillage, residues removed, $C=0.10$.

II. 1975

A. Woodland

1. Grazed, medium stocked stand, 40 to 70 percent tree canopy, 70 percent litter cover, $C=0.03$

2. Ungrazed, well stocked stand, 75 to 100 percent tree canopy, 90 to 100 percent litter cover, $C=0.001$.

B. Pasture

Bluegrass, no appreciable canopy, 85 percent ground cover, $C=0.011$.

C. Farmyard

Grass, no appreciable canopy, 50 percent ground cover, $C=0.07$.

D. Cropland

1. Continuous tobacco, spring plowed, conventional tillage, residues removed from field, $C=0.45$.
2. Six-year rotation of 2 years row crop, 1 year small grain, and 3 years hay-meadow (2RO3M), conventional tillage, 50 percent fall plowed -50 percent spring plowed, 33 percent of residues left - 67 percent removed, interpolated $C=0.105$.

3. Six-year rotation of 2 years row crop, 1 year small grain, and 3 years hay-meadow (2RO3M), strip tillage, 4,000-6,000 pounds per acre of corn residue left, $C=0.05$.

4. Three-year rotation of 1 year row crop, 1 year small grain, and 1 year hay-meadow (ROM), conventional tillage, 50 percent fall plowed -50 percent spring plowed, 33 percent of residues left -67 percent removed, interpolated $C=0.085$.

5. Four-year rotation of 1 year row crop, 1 year small grain, and 2 years hay-meadow (RO2M), strip tillage, $3000-4000$ pounds per acre of corn residue left. $C=0.025$.

6. Four-year rotation of 1 year row crop, 1 year small grain, and 2 years hay-meadow (RO2M), conventional tillage, 50 percent fall plowed -50 percent spring plowed, 33 percent of residues left - 67 percent removed, interpolated $C=0.07$.

7. Five-year rotation of 1 year row crop, 1 year small grain, and 3 years hay-meadow (RO3M), conventional tillage, 50 percent fall plowed -50 percent spring plowed, 33 percent of residues left - 67 percent removed, interpolated $C=0.055$.

8. Five-year rotation of 1 year row crop, 1 year small grain, and 3 years hay-meadow (RO3M), strip tillage, $3,000-4,000$ pounds per acre of corn residue left, $C=0.02$.

9. Six-year rotation of 1 year row crop, 1 year small grain, and 4 years hay-meadow (RO4M), strip tillage, $3,000-4,000$ pounds per acre of corn residue left, $C=0.015$. 
APPENDIX III.-Average slope lengths and gradients for soils of the study area

[Data from A. J. Klingelhoets, Soil Conservation Service, Madison, written commun., 1976]

\begin{tabular}{|c|c|c|c|c|c|c|c|}
\hline \multicolumn{4}{|c|}{$\begin{array}{l}\text { APPENDIX III.-Average slope lengths and gradients for soils of the } \\
\text { study area } \\
\text { [Data from A. J. Klingelhoets, Soil Conservation Service, Madison, } \\
\text { written commun., 1976] }\end{array}$} & \multirow{4}{*}{ 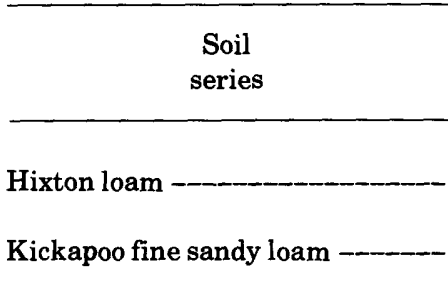 } & \multirow{3}{*}{$\begin{array}{c}\begin{array}{c}\text { Map } \\
\text { symbol }\end{array} \\
\text { HID }\end{array}$} & \multirow{3}{*}{$\begin{array}{c}\begin{array}{c}\text { Slope } \\
\text { gradient } \\
\text { (percent) }\end{array} \\
\\
16 \\
5\end{array}$} & \multirow{2}{*}{$\begin{array}{r}\begin{array}{r}\text { Slope } \\
\text { length } \\
\text { (feet) }\end{array} \\
250\end{array}$} \\
\hline & & Slope & Slope & & & & \\
\hline sories & Map & gradient & length & & & & 200 \\
\hline & & (percent) & (feet) & & KpA & 1 & 200 \\
\hline \multirow{4}{*}{$\begin{array}{l}\text { Alluvial land } \\
\text { Alluvial land, wet } \\
\text { Arenzville silt loam }\end{array}$} & Ad & 1 & 200 & \multirow{4}{*}{$\begin{array}{l}\text { Norden loam- } \\
\text { Norwalk silt loam }\end{array}$} & KpB & 2 & 150 \\
\hline & $\mathrm{Al}$ & 1 & 150 & & $\mathrm{NlF}$ & 35 & 200 \\
\hline & ArA & 1 & 400 & & NwB & 3 & 250 \\
\hline & ArB & 3 & 200 & & $\mathrm{NwC}$ & 8 & 200 \\
\hline \multirow[t]{2}{*}{ Chaseburg silt loam - } & $\mathrm{CaA}$ & 2 & 150 & & & & \\
\hline & $\mathrm{CaB}$ & 4 & 200 & Orion silt loam - & OrA & 1 & 350 \\
\hline \multirow[t]{2}{*}{ Downs-Tama silt loams - } & DmA & 2 & 450 & Oshkosh silt loam- & OsB & 3 & 300 \\
\hline & & & & & OsC & 9 & 200 \\
\hline \multirow[t]{4}{*}{ Dubuque silt loam - } & DsB & 4 & 450 & & OsD & 16 & 150 \\
\hline & DsC & 9 & 400 & Palsgrove silt loam- & $\mathrm{PaA}$ & 1 & 300 \\
\hline & DsD & 16 & 350 & 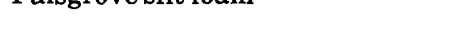 & $\mathrm{PaB}$ & 4 & 450 \\
\hline & DsE & 25 & 250 & & $\mathrm{PaC}$ & 9 & 400 \\
\hline \multirow[t]{2}{*}{ Dunbarton-Sogn Stony soils _._. } & DvD & 16 & 250 & & $\mathrm{PaD}$ & 16 & 300 \\
\hline & $\mathrm{DvE}$ & 25 & 200 & & $\mathrm{PaE}$ & 25 & 250 \\
\hline \multirow[t]{4}{*}{ Fayette silt loam, uplands - } & FuB & 3 & 350 & & & & \\
\hline & $\mathrm{FuC}$ & 9 & 300 & Rozetta silt loam & RoA & 1 & 300 \\
\hline & FuD & 16 & 250 & & RoB & 3 & 250 \\
\hline & & & & & $\mathrm{RoC}$ & 8 & 200 \\
\hline \multirow[t]{2}{*}{ Fayette silt loam, valleys } & FvD & 16 & 300 & Stony colluvial land & $\mathrm{ScA}$ & 2 & 150 \\
\hline & $\mathrm{FvF}$ & 35 & 250 & & $\mathrm{ScB}$ & 4 & 100 \\
\hline \multirow[t]{3}{*}{ Gale silt loam - } & $\mathrm{GaB}$ & 4 & 300 & Stony rock land - & $\mathrm{SkE}$ & 25 & 350 \\
\hline & $\mathrm{GaC}$ & 8 & 250 & & SkF & 35 & 350 \\
\hline & $\mathrm{GaE}$ & 25 & 200 & Stronghurst silt loam-_- & StB & 3 & 300 \\
\hline
\end{tabular}

4) U.S. GOVERNMENT PRINTING OFFICE: $1982-361-614 / 115$ 